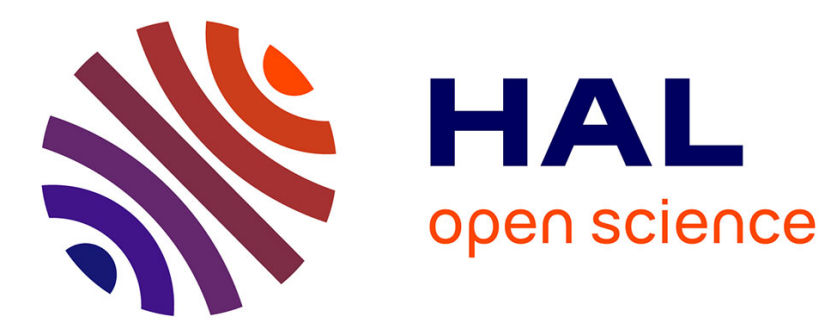

\title{
Immigration, factor endowments and the productive structure of Spanish regions, 1996-2005.
}

\author{
Guadalupe Serrano-Domingo, Francisco Requena-Silvente, Joan
}

Martin-Montaner

\section{- To cite this version:}

Guadalupe Serrano-Domingo, Francisco Requena-Silvente, Joan Martin-Montaner. Immigration, factor endowments and the productive structure of Spanish regions, 1996-2005.. Regional Studies, 2011, pp.1. 10.1080/00343404.2010.543127 . hal-00677963

\section{HAL Id: hal-00677963 https://hal.science/hal-00677963}

Submitted on 11 Mar 2012

HAL is a multi-disciplinary open access archive for the deposit and dissemination of scientific research documents, whether they are published or not. The documents may come from teaching and research institutions in France or abroad, or from public or private research centers.
L'archive ouverte pluridisciplinaire HAL, est destinée au dépôt et à la diffusion de documents scientifiques de niveau recherche, publiés ou non, émanant des établissements d'enseignement et de recherche français ou étrangers, des laboratoires publics ou privés. 


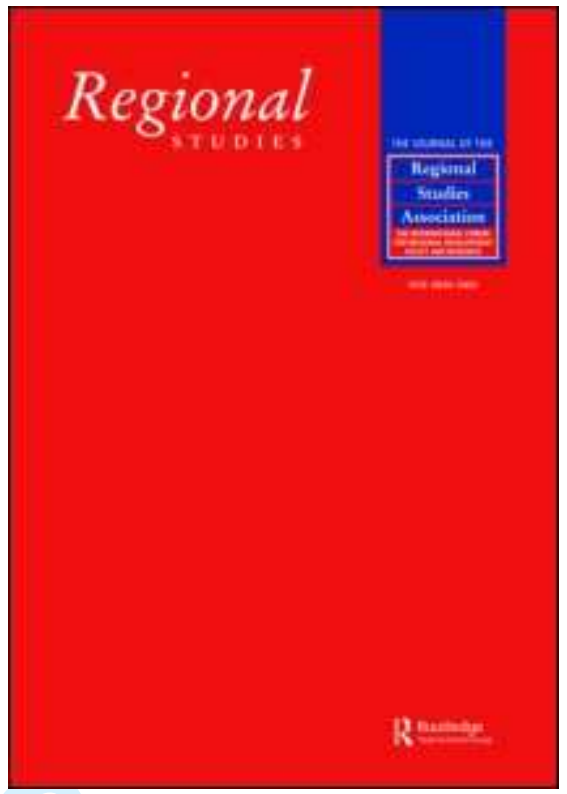

\section{Immigration, factor endowments and the productive structure of Spanish regions, 1996-2005.}

\begin{tabular}{|c|l|}
\hline Journal: & Regional Studies \\
\hline Manuscript ID: & CRES-2009-0136.R2 \\
\hline Manuscript Type: & Main Section \\
\hline JEL codes: & $\begin{array}{l}\text { F22 - International Migration < F2 - International Factor } \\
\text { Movements and International Business < F - International } \\
\text { Development, and Changes < R1 - General Regional Economics }<\text { R } \\
\text { - Urban, Rural, and Regional Economics, R13 - General Equilibrium, } \\
\text { Welfare Econ. Regional Economies < R1 - General Regional } \\
\text { Economics < R - Urban, Rural, and Regional Economics }\end{array}$ \\
\hline Keywords: & $\begin{array}{l}\text { Rybczynski effect, immigration, production specialisation, } \\
\text { technological change }\end{array}$ \\
\hline
\end{tabular}

\section{SCHOLARONE \\ Manuscripts}




\title{
Immigration, factor endowments and the productive structure of Spanish regions, 1996-2005.
}

\author{
Guadalupe Serrano+, Francisco Requena**, Joan Martin-Montaner * \\ * Dept. of Economics \\ Universitat Jaume I de \\ Castelló \\ C/ Vicente Sos Baynat, s/n \\ 12071 Castelló. Spain \\ Phone. +34964728609 \\ Fax. +34964728591 \\ E-mail: jmartin@eco.uji.es \\ ** Dept. of Applied Economics \\ Faculty of Economics \\ University of Valencia \\ Avda dels Tarongers sn. Campus dels \\ Tarongers \\ 46022 Valencia. Spain \\ Phone: +34 963828851 . \\ Fax: +34 963828249 . \\ E-mail: francisco.requena@uv.es \\ + Dept. of Economic Analysis. \\ Faculty of Economics \\ University of Valencia \\ Avda dels Tarongers sn. Campus \\ dels Tarongers \\ 46022 Valencia. Spain \\ Phone: +34 963828247 . \\ Fax: +34 963828249 . \\ E-mail: guadalupe.serrano@uv.es
}

(Received May 2009: in revised form November 2010) 


\begin{abstract}
Participation of immigrants in Spanish labour market increased from less than 3 percent in 1996 to more than 13 percent in 2005. We use the factor proportion model of production to examine the impact of such a large labour supply shock on the industrial structure of Spanish regions. The results confirm that, first, labour endowment differences across regions help to explain the regional patterns of industry specialisation. Second, immigrants and natives act as complementary factors in most industries. Third, the importance of immigration is relatively small compared to production technique changes and idiosyncratic industry changes in explaining the overall changes in industrial structure.
\end{abstract}

Key Words: Rybczynski Effect, immigration, production specialisation, technological change.

JEL: F22, R11, R13 


\title{
Inmigración, dotaciones factoriales y estructura productiva de las regiones españolas, 1996-2005.
}

\author{
Guadalupe Serrano+, Francisco Requena**, Joan Martin-Montaner *
}

\begin{abstract}
Resumen. La participación de los inmigrantes en el mercado de trabajo español aumentó desde menos de un 3\% en 1996 hasta más de un 13\% en 2005. En el marco del modelo de producción de proporciones factoriales, analizamos el impacto de este shock de oferta de trabajo en la estructura productiva de las regiones españolas. Los resultados apuntan que: las diferencias en las dotaciones factoriales regionales determinan los patrones regionales de especialización industrial; los inmigrantes y los nativos actúan como factores complementarios en muchos sectores; y en la explicación de los cambios en la estructura productiva, la importancia de la inmigración es relativamente pequeña comparada con la de los cambios tecnológicos y de las características idiosincrásicas sectoriales.
\end{abstract}




\section{INTRODUCTION}

Large migration flows can be viewed as labour supply shocks which affect the relative factor endowments in both the source and the host economy. If the skill endowments of migrant workers strongly differ from those of native workers in the host countries, then it is likely that the factor intensities in different sectors may be affected. This could be one explanation for the observed differences in wages of more-skilled relative to less-skilled workers in the developed countries over the nineties (Davis and Reeve, 2004). This migratory phenomenon may also induce (or prevent) technological adjustments, as the adoption of new capital-intensive technologies could be delayed when low-skilled labour is a relative abundant factor (Lewis, 2004; Gandal et al., 2004).

In this paper we analyse the impact of immigration on Spanish regions' industrial compositions by quantifying the extent to which the rise of the immigrant labour force has caused a shift in the industrial specialisation pattern of the regional economies. To do so, we adopt a general equilibrium approach -the factor proportions model of production- to explain up to which point changes in industrial structure of economies are driven by shifts in factor endowments, with independence of those specific changes happening in each industry. ${ }^{1}$ This approach was popularised by Harrigan (1995) as an empirical tool for investigating the shifts in production composition in an economy over time. Harrigan found that relative factor endowments had a large influence on industrial specialisation across OECD countries over the period 1970-1985. ${ }^{2}$ Bernstein and Weinstein (2002) evaluate the prediction capacity of the standard factor proportions theory using both regional and international data. They observed that prediction errors using intra-national data were much larger than using international data and concluded that the standard factor proportions model of 
production does a poor job of explaining production patterns at regional level. Redding and Vera-Martin (2006) analyse the regional pattern of output specialisation in Europe and find that it is necessary to account for technological differences and price differences across countries in the standard factor proportion model to predict accurately the pattern of industrial specialisation of the European regions. Based on previous research we adopt the standard factor proportion model of production in our analysis of the pattern of specialization of Spanish regions and check for technological and price differences across regions.

A novelty of the paper is the incorporation of immigrants as an additional production factor. The underlying assumption is that immigrants and native workers are imperfect substitutes. Recent papers by Carrasco et al. (2008), Izquierdo et al. (2009) and De la Rica and Dorantes (2009) provide empirical support in the case of Spain. First, there is evidence of important occupational segregation, in line with the popular idea that immigrants are employed in jobs that native workers do not want. Second, there are important institutional barriers (such as the existence of regional languages and the need for public recognition of the educational degree) that limit the access of foreign workers to be employed in certain jobs (professional services with a university degree, jobs in the public sector). Third, the arrival of immigrants is recent and has occurred very quickly so there has been insufficient time for complete assimilation. The foreign labour force in Spain increased from $2.7 \%$ of the total labour force in 1996 to an astonishing $13.3 \%$ in 2005 . The existence of important institutional barriers, the lack of sufficient time for cultural assimilation and the fact that there are vacancies which require skills that foreign workers have, are three reasons that explain why immigrant workers with 
the same level of education as their native colleagues are not being employed in the same occupations.

Finally, and despite the strong efforts made by both private and public agents to increase the level of $\mathrm{R} \& \mathrm{D}$ expenditures, the adoption of new technologies in certain manufacturing and services activities in Spain has been slow compared to other European countries (OECD, 2005). A plausible reason is the type of technologies required to accommodate the new inflows of workers in sectors that use the new production factor more intensively. Therefore, knowing whether production in each sector varies because of changes in endowments or because of the adoption of new technologies becomes a key point in the analysis.

The rest of the paper is structured as follows. First, we formalise the production side of the factor proportions model and its extensions to accommodate differences in prices and technology across regions. Second, we present the data and describe the evolution of the foreign and native labour force in the period 1996-2005. Third, we estimate the model using different levels of regional and sectoral aggregation and interpret the Rybczynski coefficients. Fourth, we allow the Rybczynski coefficients to change over time and assess the relative importance of changes in factor endowments and changes in production techniques in explaining changes in industrial specialisation. Finally, we summarize our results in the conclusions section.

\section{THE PRODUCTION SIDE OF THE FACTOR PROPORTIONS MODEL}

In this section we describe the factor endowment production function, originally proposed by Harrigan (1995) and extended recently by Harrigan and Zakrajšek (2000), 
Reeve (2006) and Redding and Vera-Martín (2006) to accommodate differences in technology and factor prices across countries and regions.

\subsection{Theoretical foundations}

The core insight of the factor proportions model is that regions tend to produce relatively more of those goods that intensively use the factors of production that the region has in abundance. Thus, relative factor endowments become the determinant of industrial structure and the source of comparative advantage.

Under constant-returns-to-scale technology and perfect competition in goods and factor markets, a country's national product is given by its revenue function $\Pi(\mathrm{P}, \mathrm{V})=\max _{\mathrm{Y}}\{\mathrm{PY} \mid \mathrm{Y} \in \boldsymbol{Y}(\mathrm{V})\}$ where $\mathrm{P}$ is an $(\mathrm{N} \times 1)$ vector of goods prices, $\mathrm{V}$ is an $(\mathrm{M}$ $\times 1)$ vector of inelastic factor supplies, $\mathrm{Y}$ is an $(\mathrm{N} \times 1)$ vector of net outputs, and $\boldsymbol{Y}(\mathrm{V})$ is a compact production set. Assuming $\Pi(\mathrm{P}, \mathrm{V})$ is twice continuously differentiable, the gradient with respect to $\mathrm{P}$ gives the net supply vector, $\mathrm{Y}=\Pi_{\mathrm{p}}(\mathrm{P}, \mathrm{V})$. Differentiating again with respect to factor supplies gives the matrix of Rybczynski derivatives, $R=\Pi_{P V}(P, V)$. Since the supply function is homogeneous of degree one in $\mathrm{V}$,

$$
\mathrm{Y}=\mathrm{RV}
$$

and net output is a linear function of factor endowments. ${ }^{3}$

The underlying condition that allows the $\mathrm{R}$ matrix to be identical across regions and thus equation (1) to be used as a model of interregional location of production is that regions must be able to produce the same set of goods with the same techniques. Producing the same set of goods requires relative factor endowments not to be "too" 
dissimilar across regions. ${ }^{4}$ The fact that regions use the same techniques of production depends on common technologies and factor prices. Good prices will be equalized across regions with free trade and zero transport costs. A crucial condition for factor price equalization is that the number of goods exceeds the number of factors, $\mathrm{N} \geq \mathrm{M}$. However, in order for the supply function to be singly-valued, there must be at least as many factors as goods, $M \geq N$. Thus, what is left is the "square" model in which there are equal numbers of goods and factors, $\mathrm{N}=\mathrm{M}$. In this case, equation (1) holds for each region and forms the basis for the empirical work to follow. Obviously there are more goods than factors and therefore there does not exist a unique mapping between factor endowments and production. Nevertheless, the existence of a structural relationship between factor endowments and production is all that really matters for the present analysis. $^{5}$

A final point is that the use of a general equilibrium relationship between production structure, relative prices, technology and factor endowments holds irrespective of the degree of factor mobility. ${ }^{6}$

\subsection{Empirical model.}

Equation (1) can be rewritten for each industry in each year with an additive error term as

$$
Y_{c t}^{i}=v_{c t} R_{t}^{i}+\varepsilon_{c t}^{i}
$$

Here, $Y_{c t}^{i}$ is region $c$ 's value added in industry $i$ in year $t$ and $v_{c t}$ is region $c$ 's $(1 \times \mathrm{M})$ vector of factor endowments in year $t$. The $(\mathrm{M} \times 1)$ vector $R_{t}^{i}$ represents the factor 
proportions mapping from endowments to outputs for industry $i$. Collecting observations across regions and years, we get:

$$
Y^{i}=V R^{i}+\varepsilon^{i}
$$

for industry $i$. Now, $Y_{i}$ and $\varepsilon_{i}$ are $(\mathrm{CxT} \times 1)$ vectors and $V$ is the $(\mathrm{CxT} \times \mathrm{M})$ endowment matrix.

Rather than estimating each equation individually, a multivariate regression model is built in such a way that each equation represents equation (3) for a particular industry $i$.

$$
\left[\begin{array}{c}
Y^{1} \\
\therefore \\
Y^{i}
\end{array}\right]=\left[\begin{array}{cc}
V & R^{1} \\
\therefore \\
V & R^{i}
\end{array}\right]+\left[\begin{array}{c}
\varepsilon^{1} \\
\therefore \\
\varepsilon^{i}
\end{array}\right]
$$

The main advantage of this approach is the ability to test homogeneity hypotheses across equations, i.e. across industrial branches belonging to the same sector. Moreover, since it is likely that the disturbances across equations are correlated, the multivariate approach may lead to efficiency gains and account for inter-industry externalities, an issue that has not been addressed in previous studies.

Next we allow for a more flexible specification that relaxes the assumptions on identical prices and technology among regions. In order to do so the model becomes (4a).

$$
\left[\begin{array}{c}
Y^{1} \\
\therefore \\
Y^{i}
\end{array}\right]=\left[\begin{array}{cc}
V & R^{1} \\
\therefore \\
V & R^{i}
\end{array}\right]+\left[\begin{array}{c}
D_{\tau} \phi_{\tau}^{1} \\
\therefore \\
D_{\tau} \phi_{\tau}^{i}
\end{array}\right]+\left[\begin{array}{c}
\varepsilon^{1} \\
\therefore \\
\varepsilon^{i}
\end{array}\right]
$$

Where $\tau$ refers to "periods of time": the 1996-2000 period of low immigration in Spanish regions and the 2001-2005 period of high immigration in Spain. Here, $\mathrm{D}_{\tau}$ 
captures any industry-specific impact of changes in prices and technology over the $\operatorname{period} \tau$.

The model can also be extended to accommodate time-invariant regional differences in relative prices and technology, by adding a time-invariant regional fixed effect, $D_{Z}$, with dimension $[(\mathrm{CxT}) \times \mathrm{Z}]$, and its correspondent vector of $\left[\begin{array}{lll}\mathrm{Z} & \mathrm{x}\end{array}\right]$ parameters, $\phi_{Z}$, where $\mathrm{C}$ denotes the spatial dimension of the data that we are using NUTS-2 Spanish Autonomous Communities or NUTS-3 Spanish provinces - while Z always is referred to NUTS-II Spanish Autonomous Communities. ${ }^{7}$ This is illustrated in model (4b).

$$
\left[\begin{array}{c}
Y^{1} \\
\therefore \\
Y^{i}
\end{array}\right]=\left[\begin{array}{cc}
V & R^{1} \\
\therefore \\
V & R^{i}
\end{array}\right]+\left[\begin{array}{c}
D_{\tau} \phi_{\tau}^{1} \\
\therefore \\
D_{\tau} \phi_{\tau}^{i}
\end{array}\right]+\left[\begin{array}{c}
D_{Z} \phi_{Z}^{1} \\
\therefore \\
D_{Z} \phi_{Z}^{i}
\end{array}\right]+\left[\begin{array}{c}
\varepsilon^{1} \\
\therefore \\
\varepsilon^{i}
\end{array}\right]
$$

A final extension consists on allowing region-specific differences in prices and technology to vary over time, by including a set of region-time dummy variables, $D_{Z \tau}$, with dimension $[(\mathrm{CxT}) \times(\mathrm{Zx} 2)]$, and its correspondent vector of $[(\mathrm{Zx} 2) \times 1]$ parameters, $\phi_{Z \tau}$, as shown in model (4c).

$$
\left[\begin{array}{c}
Y^{1} \\
\therefore \\
Y^{i}
\end{array}\right]=\left[\begin{array}{cc}
V & R^{1} \\
\therefore \\
V & R^{i}
\end{array}\right]+\left[\begin{array}{c}
D_{\tau} \phi_{\tau}^{1} \\
\therefore \\
D_{\tau} \phi_{\tau}^{i}
\end{array}\right]+\left[\begin{array}{c}
D_{Z \tau} \phi_{Z \tau}^{1} \\
\therefore \\
D_{Z \tau} \phi_{Z \tau}^{i}
\end{array}\right]+\left[\begin{array}{c}
\varepsilon^{1} \\
\therefore \\
\varepsilon^{i}
\end{array}\right]
$$

We estimate equations (4a), 4(b) and (4c) and test for the best specification using different geographic units and levels of industry aggregation.

\section{DATA.}


The dependent variable in our study is annual production by geographical unit and industry. Industry's output is measured by means of sector GVA (gross value added) at current basic prices from the homogeneous series of INE's Regional Accounts base year 2000. The database provides regional value added at two different geographical levels: 17 regions $\left(\right.$ NUTS-2) ${ }^{8}$ which can be disaggregated into 52 provinces (NUTS-3). The number of industries varies depending on the level of geographical aggregation. There are 21 sectors (S-21) for NUTS-2, which are grouped into 5 sectors (S-5) for NUTS-3: Agriculture, Energy, Manufacturing, Building and Services. Table A-1 in the Appendix displays the correspondence between S-21 and S-5. The period of analysis is 1996-2005.

Endowment data includes three primary factors: arable land, capital stock and labour. Labour is split into native and foreign workers and into three educational categories: low, medium, and high-educated workers, to account for differences in human capital in the labour force. Data on arable land is provided by INE's Statistical Yearbook of Spain and data on capital stock is provided by the BBVA Foundation and IVIE (http://www.ivie.es/banco/stock2.php). Labour endowments come from INE's Economically Active Population Survey (EPA, 2005 methodology). Low-educated workers include illiterates and workers with only primary education. Medium-educated workers have completed secondary school. High-educated workers have at least enrolled in a high education degree. The Appendix provides a detailed explanation of the construction of the variables.

(Insert Table 1 approximately here)

Immigrants increased their participation in the Spanish labour market from less than 3 percent in 1996 to more than 13 percent in 2005. Table 1 shows that the newly 
arrived foreign population possesses a different composition of education levels compared to natives. Over the period 1996-2005, the percentage of natives decreased among low-educated actives and increased among high-educated actives; meanwhile the percentage of immigrants among low-educated actives stayed the same and decreased among high educated actives. Skill-upgrading within the immigrant group occurred only at the medium-educated level in which the share of immigrants increased by 4 percent from 1996 to 2005 . Table 1 also shows that the foreign labour force is more heterogeneously distributed across Spanish provinces than across regions. Moreover, by education level, high-educated foreign actives are the most heterogeneously distributed across regions.

\section{(Insert Figure 1 approximately here)}

Figure 1 shows the map of Spain where NUTS-3 provinces (left map) and NUTS 2 regions (right map) are coloured according to their share of foreign-born workers within the total labour force in year 2005. While all but three provinces in 1996 have a share of foreign-born workers below 6 percent, in 2005 there were 15 provinces with shares above 13 percent. At NUTS-2 level (regions), Madrid, Baleares, Murcia, Comunidad Valenciana and Canarias contain a share of foreign actives higher than 18 percent. The highest concentration can be found, at NUTS 3 level (province), in Alicante, Almeria, Baleares, Castellon, Gerona and Madrid, which exhibit shares of foreign activity that range between 20 and 30 percent. As shown in Figure 2, mediumeducated workers are the dominant education category among both native and foreign actives in all the regional units. Finally Figure 3 shows that the sectors that employ more foreign workers are Agriculture, Building and Services (mostly Trade and Hotels and Household Services). Additionally, the distribution of natives and immigrants is 
slightly different across sectors. The share of native workers in Industry is larger than in Building, while the opposite holds for immigrant workers. Only in Agriculture both types of workers are almost equally distributed.

(Insert Figure 2 approximately here)

(Insert Figure 3 approximately here)

\section{MODEL SPECIFICATION AND ESTIMATION}

We conduct the analysis from the two different data-sets referring to different geographic units in the Spanish economy. As we can also aggregate Spanish provinces from NUTS-3 to NUTS-2, we can perform our analysis both for S-5 and S-21 classifications. This latter possibility allows us to explore differences in the estimates due to different levels of spatial and industrial aggregation. ${ }^{9}$

Models (4a)-(4c) are estimated considering the eight productive factors described in the previous section. When data correspond to S-5 disaggregation, we estimate two five-equation SUR models both for provincial and regional data. ${ }^{10}$ Nevertheless, computational capabilities do not allow the estimation of a 21-equation SUR model. Because of this, we estimate a single equation model for Agriculture and Building whereas SUR specifications are estimated for Energy (two equations), Industry (ten equations) and Services (seven equations).

Through the analysis, sector Gross Value Added (GVA) for each region and the regional gross capital stock are measured in current prices. To control scale effects due to differences in the size of region, sectoral outputs and regional inputs are expressed in relative terms with respect to regional GDP, which is measured in current prices. Moreover, to avoid heteroskedasticity problems in each equation, we specify a SUR 
model with weighted equations, in which each weight is obtained from the equation's robust estimation. Then, the estimates of the cross-equation covariance matrix are based upon GLS parameter estimates of the weighted system.

We start selecting the best model specification. Table 2 reports the mean absolute percent errors (MAPE) by industry and regional units for the models (4a), (4b) and (4c) in columns (ii), (iv) and (v) respectively. ${ }^{11}$ As a crude benchmark for comparison, these percent errors are contrasted with those based on the estimation of relative production using the cross-sectional mean. This naïve estimator in the estimation without dummy variables, column $(i)$, has an overall mean absolute percent error of 66.5 and 66.4 percent for provinces and for regions, respectively; that is 30 percentage points larger than the average error based on the factor proportions model. In addition, the naïve estimator percent error is larger than the overall mean absolute percent error in all sectors. ${ }^{12}$

As was expected, the factor proportion model of production performs better at a regional level (NUTS-2) than at a province level (NUTS-3). Thus, in the estimation without regional dummies, column $(i)$, the MAPE is 35.3 percent for provinces higher than the one in the specification for regions (27.2 percent). Following the same trend, the MAPE is smaller across regions than across provinces in those models including time and regional dummies. Our results contrast with those of Bernstein and Weinstein (2002), which report a MAPE of 310 percent using data on Japanese regions. More striking is the fact that our largest MAPE, 35.3 percent in the provincial model without dummies, is smaller than any other percent error reported by papers using international data. $^{13}$

(Insert Table 2 approximately here) 
Table 2 also reports an LR test for the global significance of estimates and the AIC criterion for model selection. According to this last criterion, the better specification is (4c) in both S-5 and S-21 cases. This specification, which corresponds to an augmented factor proportion model of production, is such that regional dummies capture differences in technology and prices that are not permanent but change over time. This conclusion is confirmed by three additional tests. First, we always reject the null hypothesis that the coefficients of the regional dummies are zero. Second, we reject the homogeneity of regional effects obtaining evidence supporting the fixed effects model specification. Finally, we test whether the coefficients for the regional dummy variables are constant over time (model $4 \mathrm{~b}$ vs $4 \mathrm{c}$ ), being that the hypothesis is always rejected.

Finally, we analyse the validity of the SUR specification by testing the null hypothesis of no correlation of the residuals between equations independently estimated. The results of the Breusch-Pagan test do reject the null hypothesis, confirming the adequacy of the SUR estimation of the model (being the exception Energy in the specifications (i) and (ii) with 21 sectors).

The analysis of the MAPE obtained in the S-5 model and in the S-21 model shows negligible differences, which does not support the idea that production indeterminacy is mainly due to the fact that the number of goods is larger than the number of factors. We perform a last test to choose between S-5 (Table A-2 in the Appendix) and S-21 (Table A-3 in the Appendix) using regional level data. Using the S5 and S-21 sectoral correspondence in Table A-1 in the Appendix, we test the equality of Rybczynski parameters across those S-21 branches belonging to the same S-5 sector. The test results displayed in the last row of Table A-2 for model (4c), which includes 
time-varying regional dummy variables, show that the equality of Rybczynski coefficients is rejected for branches belonging to Energy, Industry and Services. Because of that, we selected model (4c) using regional data (NUTS 2) and 21 sectors as our best specification. Estimates are displayed in Table A-3 and the findings are explained in the next section.

\section{IMMIGRATION IN THE FACTOR PROPORTION MODEL OF PRODUCTION.}

In this section we use the Rybczynski coefficients to investigate the impact of immigration on the production structure of Spanish regions. The sign and significance of the coefficients can be interpreted in terms of comparative advantage (Leamer, 1984). Profit-maximizing firms adapt to changes in relative endowments, according to the differences in benefits that can be drawn from an increase in the endowment of each factor. Thus, productive factors are reallocated across sectors and that reallocation might imply increases and reductions of production depending on the sector. Therefore, a positive sign for the corresponding Rybczynski coefficient means that the increase in one region's endowment of a certain factor translates into an increase in production in that sector (or, in other words, represents a source of comparative advantage), whereas a negative sign means that the accumulation of that factor leads to a reduction of the production of the sector (representing, therefore, a comparative disadvantage). ${ }^{14}$ Table 3 reports the beta coefficient estimates. Beta coefficients indicate the relevance of the explanatory variable in the regression, since they measure the expected change in the standardised dependent variable induced by a unitary change in the standardised independent variable, which is conditional on the other standardised regressors. ${ }^{15}$

(Insert Table 3 approximately here) 
The coefficient on capital is significant in most sectors, although only displays a positive sign in branches 3 (Electricity, gas and water), 4 (Food, drink and tobacco), 14 (Building), 19 (Renting and business services) and 20 (Education, health and other services). The coefficient on land is also significant in most branches, playing a positive impact in branch 1 (Agriculture), 6 (Wood Products), 14 (Building), 18 (Financial Services), 19 (Renting and business services) and 20 (Education, health and other services). With regard to the native labour force, the coefficient on medium-educated workers appears to be positive and significant in most sectors (17 branches out of 21). For high-educated workers the coefficient is positive and significant in Energy and Services branches, whereas for low-educated workers the coefficient exhibits mixed signs across sectors.

With regard to immigrants, our results display a high degree of heterogeneity in terms of significance. The coefficient on medium-skilled immigrants is significant in 14 branches (in most cases negative), whereas for high-skilled immigrants it shows a statistically significant coefficient only in 6 branches. Low-skilled immigrants are in an intermediate position, with a statistically significant coefficient in 9 branches, most of them in the Industry sector. The significant, unexpected absence of less-skilled immigrants in Agriculture and Building can be explained by the fact that our data do not include undocumented workers which would likely enlarge the amount of foreign workers in that sector. Another striking result comes from the Industry sectors, where the impact of low and medium-educated foreign workers is negative in all its branches. This negative impact can be interpreted as foreign workers constituting a source of comparative disadvantage. This could explain both the small number of overall 
immigrants in Industry and the fact that they tend to be medium-level educated (some qualifications are required, but not as many as to require high-qualified workers).

We analyse next the kind of relationship, if any, that exists between foreign and native workers. Table 4 shows the results of testing the equality of the parameters for native and immigrant workers at different skill levels. The results are mixed. The hypothesis of equal parameters for high-qualified workers is only rejected in two cases: sectors 7 (Paper and printing) and 13 (Miscellaneous). This is not surprising as the coefficients of both native and foreign high-qualified workers are the only significant ones in these two sectors. The equality of the parameters for medium-qualified workers is rejected in all the cases in which both native and foreign workers exhibit statistically significant coefficients (sectors 1, 2, 4, 5, 6, 7, 10, 13, 15 and 17) and it is not rejected in two cases: 3 (Electricity, gas and water) and 20 (Education, health and other services). In these two cases the coefficient of both types of workers is positive. Finally, in the case of low-qualified workers, equality is only rejected in three sectors: branches 4 (Food, drink and tobacco), 9 (Plastic and Rubber) and 10 (Metal industries and nonmetallic products).

(Insert Table 4 approximately here)

In general, it can be observed that the coefficient on immigrant workers is not significant unless the coefficient on native workers is also significant. We observe that only in 9 out of 63 cases the coefficient for a type of immigrant worker is statistically significant when the coefficient of the native counterpart is not statistically significant. This outcome is partly explained by the high standard errors in the estimated coefficients associated with the immigrant worker variables (see Tables A-2 and A-3). Given the asymmetry of estimated effects for native and foreign workers in most sectors, 
it is not possible to point to any accumulation or compensation effect of foreign workers relative to native ones, but there is a sort of interrelation between both types of labour, especially for medium-qualified workers.

\section{FACTOR ACCUMULATION AND INDUSTRIAL STRUCTURE CHANGES FROM 1996 TO 2005}

Although factor endowments have been proved to be significant in determining the value added for the different sectors, changes in the productive structure can also be caused by both changes in the level of those endowments or in the way they are combined to produce. In order to incorporate the possibility of changes in production techniques, we need to test the stability of the Rybczynski parameters over the period analysed. Table 3 reports the Wald test statistics for the null hypothesis of equality of coefficient estimates for the periods of 1996-2000 and 2001-2005. The null hypothesis of constant coefficients can be rejected at standard levels of significance in all the cases. Therefore changes in the techniques of production over the entire period 1996-2005 could be an important source of change in industrial structure.

In order to identify the relative importance of the forces acting on production structures, the estimation results from Equation (4) can be used to decompose the change in output from $t-n$ to $t$ as:

$$
Y_{i}^{t}-Y_{i}^{t-n}=\left(V^{t}-V^{t-n}\right) \hat{\bar{R}}_{i}+\bar{V}\left(\hat{R}_{i}^{t}-\hat{R}_{i}^{t-n}\right)+\left(\hat{\varepsilon}_{i}^{t}-\hat{\varepsilon}_{i}^{t-n}\right)
$$

where $\bar{V}$ is the average value of factor endowments in years $\mathrm{t}$ and $\mathrm{t}-\mathrm{n}$, and $\hat{\bar{R}}_{i}$ is the average estimated coefficient matrix in periods $\mathrm{t}$ and $\mathrm{t}-\mathrm{n}$ for industry $\mathrm{i}$. The first term, $\Delta_{n} V \hat{\bar{R}}_{i}$ captures the contribution of changes in factor endowments, holding fixed $\hat{\bar{R}}_{i}$, 
the estimated techniques of production. The Rybczynski theorem characterises how output responds to changes in endowments at fixed prices and technology, i.e. at fixed techniques of production. Hence, the term $\Delta_{n} V \hat{R}_{i}$ can also be interpreted as the Rybczynski effect. The second term in Equation (5), $\bar{V} \Delta_{n} \hat{R}_{i}$, is the effect that changes in production techniques have on shifts in production, holding fixed endowments. Here, "technique" refers to factor usage which depends on technology (i.e. the production function) as well as relative factor prices. ${ }^{16}$ The final term, $\Delta_{n} \hat{\varepsilon}_{i}$, is the difference in the residuals.

Table 5 shows the decomposition analysis in equation (5) used to determine the percentage contribution of changes in factor endowments and technology to variations in value added between 1996-2000 and 2001-2005. The values reported are the percentage contributions of the terms in equation (5), expressed as cross-country averages. ${ }^{17}$ The overall contribution of factor accumulation, across all industries and years, is about 7.2 percent. Changes in the techniques of production contribute about 47.5 percent. The residual term comprises the remaining 45.4 percent. In general terms, these results give little room for changes in factor endowments to play a relevant role. In fact, they factor endowments are the dominant source of change only in the case of branch 14 (Building), and represent more than 10 percent in branches 20 (Education, health and other services) and 21 (Household services). Nevertheless, changes in techniques appear to have contributed more in most cases, followed by the regionspecific changes of each sector which are included in the residual term.

(Insert Table 5 approximately here) 
The residual term in Table 5 represents a high share of the change in sector output in most cases. This term includes all regional issues beyond technology and endowments which may affect the regional value added per sector. In order to reduce this residual term and put on the front some of these regional issues, an alternative decomposition has been attempted.

In our estimates, we controlled scale effects due to differences in the size of the region by expressing sectoral output and regional inputs in relative terms with respect to regional GDP. Therefore model (2) can be rewritten for each industry in each year as $\frac{Y_{c t}^{i}}{Q_{c t}}=v_{c t} \frac{R_{t}^{i}}{Q_{c t}}+\varepsilon_{c t}^{i}$, where $Q_{c t}$ is the aggregate region $c$ output. Following the same methodology as in (5), we decompose the change in output from $t-n$ to $t$ as:

$$
Y_{i}^{t}-Y_{i}^{t-n}=\left(V^{t}-V^{t-n}\right) \hat{\bar{R}}_{i}+\bar{V}\left(\hat{R}_{i}^{t}-\hat{R}_{i}^{t-n}\right)+\left(Q^{t}-Q^{t-n}\right) \hat{\bar{\varepsilon}}_{i}+\left(\hat{\varepsilon}_{i}^{t}-\hat{\varepsilon}_{i}^{t-n}\right)
$$

The new term, $\Delta_{n} Q \hat{\bar{\varepsilon}}_{i}$, stands for a regional effect that captures the contribution of changes in regions' relative relevance (in regions' scale) on shifts in sector production.

As shown in Table 6, the scale effect is relevant. All three initial effects are smaller than in Table 5, although the mean for the technological effect and the residual are those which decrease more. Once the scale effect is taken into account, the factor endowment effects in Building becomes smaller (accounting for just a $10.4 \%$ of total VAB variation), whereas it becomes more important in the case of Mechanical Machinery and Electric and Electronic Equipment and Transport Equipment and, even more so, in Wood Products. Finally, the "regional scale effect" represents a high share in the total variation in value added in the case of Chemical Products, Reparation and 
Commerce, Hotels and Transport and Communication Services, whereas it is negligible for other service activities such as Financial Services, Renting and Business Services, Education and Health and Household Services.

(Insert Table 6 approximately here)

\section{FINAL REMARKS.}

This paper provides the first evidence of the impact of immigration in the pattern of production specialisation across Spanish regions in the period 1996-2005. The extent to which an increase in the immigrant labour force could induce shifts in the industrial structure of regional economies is also quantified. Based on the factor proportions model of international trade, foreign and native labour force are introduced as two separate inputs in an augmented supply production function to estimate how much sectoral output varies with changes in factor endowments (the so-called Rybczynski coefficients).

The results show that both the effects of factor endowments and specific timevarying regional characteristics in each industry appear to be important in understanding industrial structure. While a higher spatial disaggregation reveals a production indeterminacy problem and a poor performance of the model, the higher sector disaggregation does not seem to generate this indeterminacy problem.

Our first finding is that the data reject the hypothesis of equality in the impact of native and foreign labour by educational type on industrial shares across Spanish regions. This result holds even when we examine those sectors in which the Rybczynski coefficients for natives and immigrants have the same sign. This can be interpreted that natives and immigrants are not perfect substitutes in the production function. 
In terms of the impact of factor endowments and its role as a source of comparative advantage across industries within Spain, the results point to a small effect caused by the presence of foreign workers. Only medium-educated foreign workers present a statistically significant impact in most of the sectors, whereas the impact of low and high-educated foreign workers appears to differ from zero in less than half of the branches considered.

If we connect these results to those showing complementarities between native and foreign labour, we can conclude that the presence of immigrants never implies the leaving of native workers from a sector, as shown by the fact that immigrant work is never statistically significant without native work also being so. In general, results suggest a sort of complementarity between natives and immigrants at the different levels of qualification, especially among the medium-educated workers.

To conclude, factor accumulation has tended to be the least important gross force acting on production. In contrast, shifts in the national techniques of production have been the more relevant source of changes in relative outputs in Spanish regions. That immigration has been one of the most important sources of change in factor endowments in Spain in recent years, a strong conclusion stems from our results: although immigration has changed the factor endowment mix across Spanish regions, it has had little impact on the changes observed in the industrial structure in Spain between 1996 and 2005.

Acknowledgements. The authors thank the two anonymous referees for valuable comments. Financial support from the Instituto Valenciano de Investigaciones 
Económicas (IVIE), the Ministerio de Ciencia e Innovación (Project number ECO 2008/04059/ECON) is acknowledged. Francisco Requena is member of PROMETEO (program Generalitat Valenciana PROMETEO/2009/098). A previous version of this research is in the IVIE's EC series Working Papers (WP-EC 2009-01)

\section{APPENDIX.}

Data sources and variable computations.

Data on Gross Value Added (GVA) have been obtained from INE's Spanish Regional Accounts Base-year 2000 information (www.ine.es). We use 1996-2005 homogenous information on current GVA, both for Spanish provinces (NUTS-3) and regions (NUTS-2), for 5 aggregated production sectors (S-5). Data on current GVA for 25 production branches is only available from the year 2000 onwards. Because of this, the need for estimating homogeneous information on current GVA for activity branches implied the reduction of activity branches considered to 21 (S-21). See Table A1.

We obtain the current GVA of the 21 branches (S-21) from the period 19961999, splitting the S-5 current GVA data, by using sector shares from information from INE's Spanish Regional Accounts Base-year 1995 data, once those shares have been corrected according to Base 2000 database revision. The main problem with sector branch classification in current Euros is found in the services sector. While the Baseyear 1995 database distinguishes between market and non-market service branches, the Base-year 2000 database does not distinguish the non-market services. Then, in order to reduce branch share differentials among both databases, we considered an aggregated "Education health, public administration and other services" branch which is obtained as a rest.

(Insert Table A-1 approximately here)

We use data from INE's Economically Active Population Survey (EPA, 2005 methodology) to measure native and foreign labour endowments. We use data on the second quarter of each year from 1996 to 2005, given its possibility of actualization using the new 2005 methodology, which is adopted explicitly to account for the large 


\section{Additional Tables.}

(Insert Table A-2 approximately here)

(Insert Table A-3 approximately here)

\footnotetext{
NOTES

${ }^{1}$ The key assumption for the present analysis is the existence of a structural relationship between factor endowments and outputs, but for our purposes, we do not need to go further into testing the factor proportion model's assumptions against alternatives or address any of its critics. Thus, the factor proportion model is a good theoretical framework to base our analysis on.
} 
${ }^{2}$ Harrigan's conclusions are shown to be robust to alternative model specifications and estimation techniques by Harrigan (1999), Harrigan and Zakrajšek (2000) and Reeve (2006).

${ }^{3}$ Equation (1) can also be derived in a monopolistic competition model with increasing returns to scale (see Harrigan, 1995). The assumption of constant returns to scale is supported by the work by Goerlich and Orts (1994) in the case of Spain.

${ }^{4}$ Regions will produce a different set of goods in the case of "lumpiness" (i.e. an excessive uneven distribution of factors across Spanish provinces). Artal et al. (2008) applied the "lens condition" test and rejects the existence of lumpiness in the case of Spain.

5 The structural relationship goes in one direction since factor endowments are exogenous in the model. However, as far as accumulation depends primarily on broad forces that are largely external to a given sector, this assumption should not be a serious problem. For example, educational attainment seems to be driven largely by demographic characteristics and domestic educational policy and capital accumulation depends on aggregate forces such as life-cycle behaviour, macroeconomic conditions, and tax policy. From a more pragmatic point of view, there are no good instruments available for factor supplies. Indeed many empirical papers use factor endowments as "good" instruments of production output, when this variable is included in the regression as an explanatory variable, under the assumption that they are exogenous.

${ }^{6}$ Redding and Vera-Martín (2006) show that the production-factor endowment relationship holds without factor price equalisation given that both differences in relative prices and technology are controlled in the model, and hold under factor 
mobility. However, the interpretation of this general equilibrium relationship changes depending on the mobility of factors. When factor immobility holds, the model can be interpreted in supply-side terms (external changes in factor endowments cause production structure changes). When factors are perfectly mobile across regions, there is also a demand-side interpretation (external changes in demand and production cause endogenous changes in factor endowments).

${ }^{7}$ As we explain in more detail later, we use both EUROSTAT NUTS-2 (17 Spanish Autonomous Communities) and NUTS-3 (52 Spanish provinces) in our analysis. Then, for NUTS-2, $C=Z$, and for NUTS-3, $C>Z$.

${ }^{8}$ The Spanish Autonomous Communities (EUROSTAT NUTS-2 classification) represent the most important administrative units at the regional level and 11 out of 17 include more than one province.

${ }^{9}$ In their study of regional production specialisation across European regions, Redding and Vera-Martin (2006) find larger, within-sample-average absolute-percent errors in disaggregated manufacturing industries, and relate it to the production indeterminacy problem given the larger number of industries relative to production factors. They also refer to the Bernstein and Weinstein (2002) explanation of production indeterminacy, "which is likely to be larger for the lower values of trade costs observed across regions within a country" (page 4).

${ }^{10}$ See Table A-2 for estimated coefficients using regional data. Estimated coefficients using provincial data are available on request from the authors.

11 MAPE $=$ mean $\left(\frac{\text { abs }(\text { Observed value }- \text { Fitted Value })}{\text { Observed Value }}\right) \cdot 100$ 
${ }^{12}$ The exceptions are Wood Products in all the specifications and Financial Services in the estimation without regional dummies.

${ }^{13}$ Using OECD country-level data, Harrigan (1995), Bernstein and Weinstein (2002) and Reeve (2006) report absolute percent errors of 40 percent, 67 percent, and 52 percent, respectively.

${ }^{14}$ Notice that the values of Rybczynski coefficients do not indicate differences in marginal value productivity. Rather the value of the coefficients indicates differences in the benefit that can be drawn from an increase in the endowment of each factor, after optimal reallocation of all factors, given the endowments of other factors.

15 Standardised or beta coefficients, discussed in Leamer (1984), are formed by multiplying the regression slope by the standard deviation of the explanatory variable and dividing by the standard deviation of the dependent variable. The actual coefficient estimates are reported in Table A-3 in Appendix.

16 Techniques can change for a wide variety of reasons. These include changes in technology and preferences. Other sources of change include trade liberalization with the rest of the world, the emergence of new industrialized trading partners, overall factor accumulation within the sample, and even industry-specific shocks. Whatever the reasons for change in techniques, they cannot be distinguished in the present framework. However, explaining the changes in the techniques is not our goal, but merely distinguishing them from the factor endowment effect.

${ }^{17}$ Since the terms in Equation (5) can be of either sign, a simple average obscures their true contributions. Therefore, the averages are reported in terms of absolute values. Moreover, these components have been normalized to sum to 100 percent. 


\section{REFERENCES}

ARTAL A., CASTILLO J. and REQUENA F. (2008) Is Spain a lumpy country? A dynamic analysis of the 'lens condition'. Applied Economic Letters, 15, 175-180

BERNSTEIN J.R. and WEINSTEIN D.E. (2002) Do endowments determine the location of production? Evidence from national and international data, Journal of International Economics, 56 (1), 55-76.

CARRASCO R., JIMENO J. and ORTEGA C. (2008) The effect of immigration on the labor market performance of native-born workers: some evidence for Spain. Journal of Population Economics, 21(3), 627-648

DAVIS D.R. and REEVE T. A. (2004) Human capital, unemployment, and relative wages, in GREENAWAY D., UPWARD R., and WAKELIN K. (eds) Trade, Investment, Migration, and Labour Market Adjustment. Palgrave Macmillan. Basingstoke, England.

DE LA RICA S. and DORANTES C. (2009) Complements or substitutes? Task specialization by gender and nativity in Spain, IZA. Discussion Papers nº4348.

FUNDACION BBVA (1999). Renta Nacional de España y su Distribución Provincial. Serie Homogénea. Tomo II. Madrid.

GANDAL N., HANSON, G. and SLAUGHTER, M. (2004) Technology, trade, and adjustment to immigration in Israel. European Economic Review, 48, 403-428.

GOERLICH F.J. and ORTS, V. (1994) Margen entre precio y coste marginal y economías de escala en la industria española (1964-1989). Revista de Economía Aplicada, 6; 29-53. 
HARRIGAN J. (1999) Technology, factor supplies, and international specialization: estimating the neoclassical model. American Economic Review, 87(4), 475-94.

HARRIGAN J. (1995) Factor endowments and the international location of production: econometric evidence for the OECD, 1970-1985. Journal of International Economics, 39: 123-141.

HARRIGAN J. and ZAKRAJŠEK E (2000) Factor supplies and specialization in the world economy. Finance and Economics Discussion Series 2000-43. Federal Reserve Board of Governors.

INE (various years). Economically Active Population Survey. The National Statistics Institute of Spain (www.ine.es).

INE. Population and Housing Census 1991. The National Statistics Institute of Spain (www.ine.es).

INE. Population and Housing Census 2001. The National Statistics Institute of Spain (www.ine.es).

IZQUIERDO M., LACUESTA A. and VEGAS R. (2009) Assimilation of immigrants in Spain: a longitudinal analysis. Labour Economics, 16, 669-678.

LEWIS E. (2004) How did the Miami labor market absorb the Mariel immigrants? Federal Reserve Bank of Philadelphia, Working Paper nº4-3. Philadelphia.

LEAMER E.E. (1984) Sources of International Comparative advantage: Theory and Evidence. MIT Press. Cambridge, MA.

REEVE T. A. (2006) Factor endowments and industrial structure. Review of International Economics. 14(1), 30-53. 
REDDING S. and VERA-MARTIN M. (2006) Factor endowment and production in European regions. Review of World Economics, 142(1), 1-32.

OCDE (2005). Estudios Económicos: España. Abril, Ediciones Multi-Prensa, España. (OECD. Economic Studies: Spain. April) 
Figure 1. Participation of foreign labour (\% total labour force). Year 2005

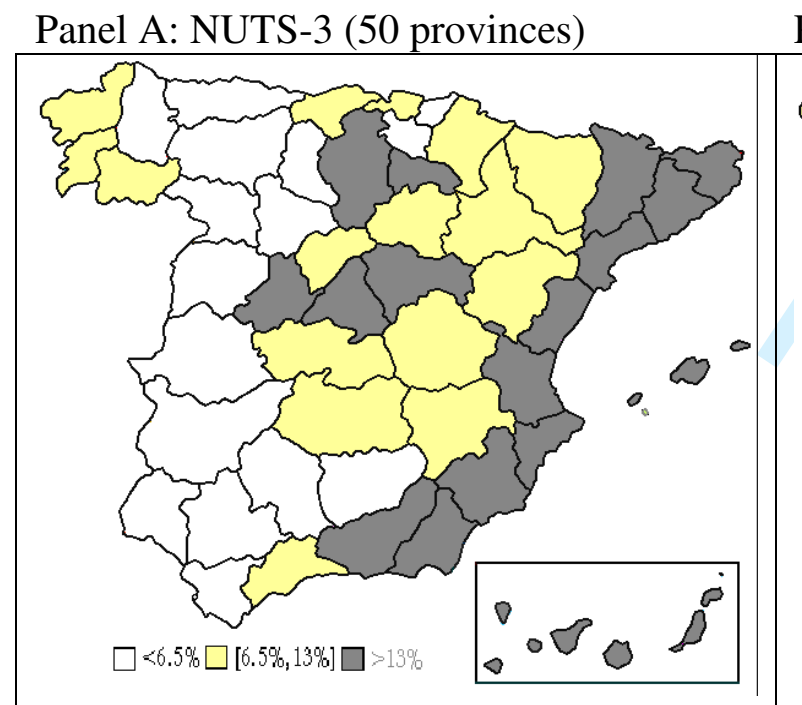

Panel B: NUTS-2 (17 regions)

Source: Own elaboration using INE's Economically Active Population Survey. 
Figure 2. Distribution of Spanish labour force by nationality, education level and territory (NUTS-2) in year 2005. (Regions are ordered - from high to low - according to the percentage of immigrants in the total labour force)

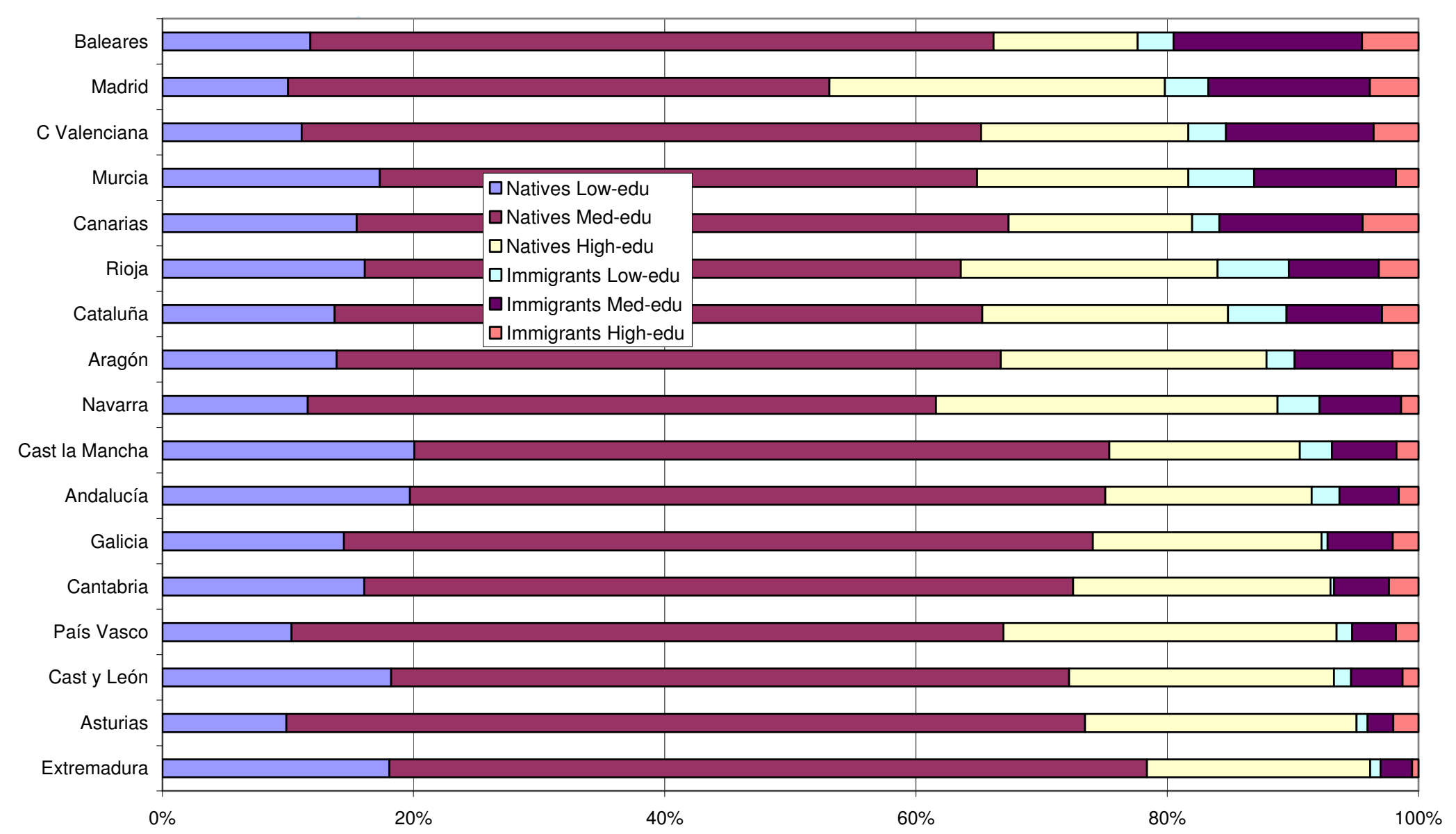

Source: INE’s Economically Active Population Survey. 
Figure 3. Share of Workers by Sector and Nationality. 2005.

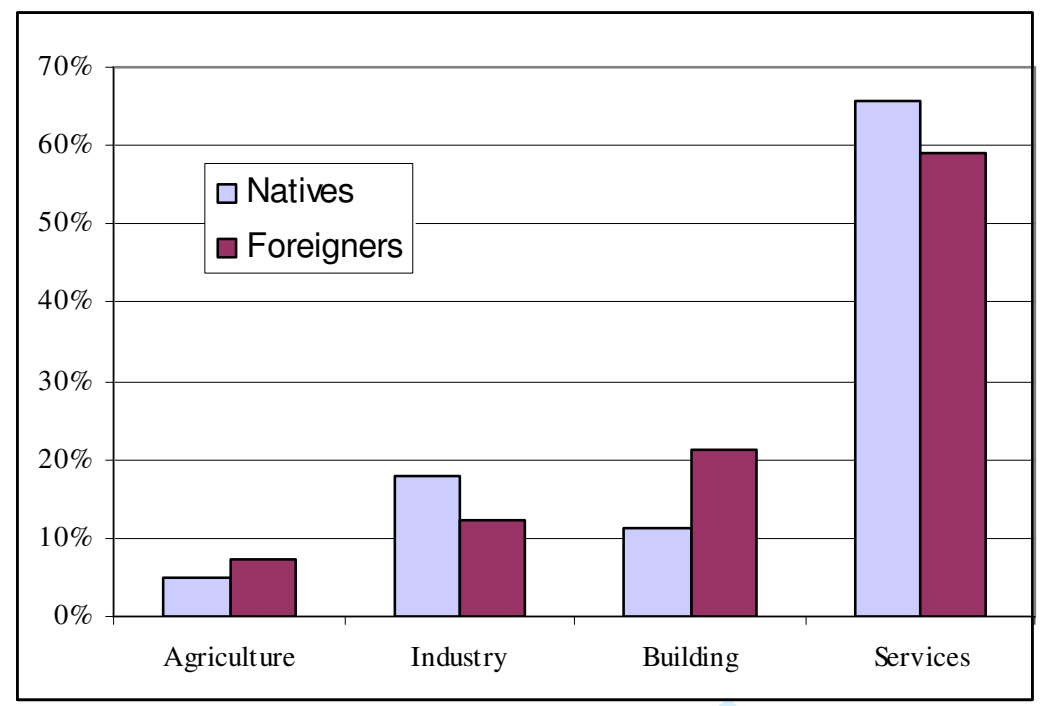

Source: INE's Economically Active Population Survey. 
Table 1. Composition of Labour Supply by Education Levels and Nationality.

\begin{tabular}{lccccr}
\hline Total & \multicolumn{3}{c}{ Total } & \multicolumn{3}{c}{ Low-edu } & \multicolumn{2}{c}{ Medium-edu High-edu } \\
& 1996 & 100 & 34,1 & 50,2 & 15,7 \\
& 2005 & 100 & 17,2 & 60,6 & 22,2 \\
Immigrants & & & & & \\
& 1996 & 2,7 & 20,9 & 55,7 & 23,5 \\
& 2005 & 13,3 & 20,9 & 59,5 & 19,6 \\
Rest of labour & 1996 & 97,3 & 34,5 & 50,0 & 15,5 \\
force & 2005 & 86,7 & 16,6 & 60,8 & 22,6
\end{tabular}

Dispersion* of labour shares by education level and nationality across Spanish provinces in 2005

$\begin{array}{lrrrr}\text { Immigrants } & 1,70 & 1,02 & 1,68 & 1,75 \\ \text { Rest of Labour force } & 14,03 & 2,77 & 8,65 & 4,20 \\ \text { Total } & & 0,86 & 0,78 & 0,59\end{array}$

Dispersion* of labour shares by education level and nationality across Spanish regions in 2005

\begin{tabular}{lrrrr} 
Immigrants & 2,04 & 1,55 & 1,86 & 2,10 \\
Rest of Labour force & 14,79 & 4,26 & 10,58 & 4,43 \\
Total & 4,53 & 15,71 & 5,20 \\
\hline
\end{tabular}

Notes: Own elaboration using Spanish Economically Active Population Survey. Education levels: Low=primary education or less; Medium=high school or equivalent; High=university degree or equivalent. * Coefficient of variation of shares of actives by education level 
Table 2. Model Specification and evaluation.

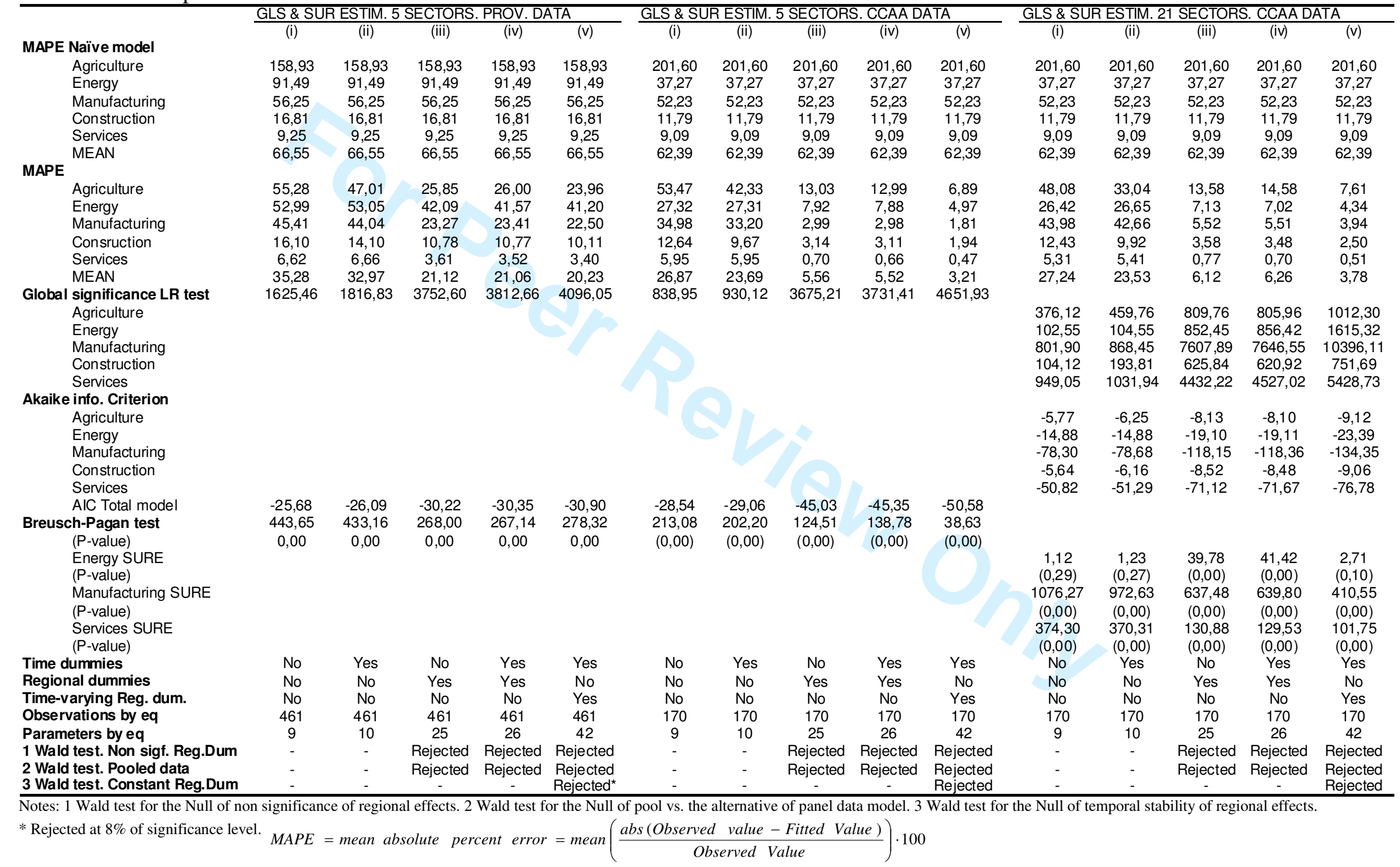


Table 3. Standardised Coefficient Estimates (1996-2005). Beta Coefficients.

\begin{tabular}{|c|c|c|c|c|c|c|c|c|c|c|c|c|}
\hline \multicolumn{2}{|l|}{ Sectors } & 1 & 2 & 3 & 4 & 5 & 6 & 7 & 8 & 9 & 10 & 11 \\
\hline \multicolumn{2}{|c|}{ Absolute Prediction error } & 7,608 & 13,147 & 4,519 & 1,848 & 12,134 & 129,865 & 3,444 & 6,437 & 7,114 & 1,493 & 3,577 \\
\hline \multicolumn{13}{|l|}{ Beta-coefficients } \\
\hline \multirow[t]{3}{*}{ Native work } & High-edu & $-0,004$ & $0,158^{* \star \star}$ & $0,192^{* \star \star}$ & 0,015 & $-0,005$ & $-0,051$ & $0,047 * *$ & $-0,014$ & $-0,008$ & $-0,018$ & $-0,014$ \\
\hline & Medium-edu & $0,086^{\star \star \star}$ & $0,261^{\star \star *}$ & $0,512^{* \star *}$ & 0,062 *** & $0,097^{\star \star \star}$ & $0,185^{\star \star \star}$ & $0,108^{* \star *}$ & $0,121^{\star * *}$ & 0,015 & $0,035^{\star *}$ & $0,061^{\star \star \star}$ \\
\hline & Low-edu & $0,147^{* * *}$ & 0,049 & $0,610^{* * *}$ & $0,107^{* * *}$ & 0,009 & 0,004 & 0,019 & $-0,006$ & $-0,034$ ** & $-0,028^{* * *}$ & 0,005 \\
\hline \multirow[t]{3}{*}{ Immigrant work } & High-edu & $-0,011$ & $-0,004$ & $-0,002$ & $-0,001$ & 0,008 & $-0,040 *$ & $0,033^{* \star *}$ & $-0,008$ & $-0,011$ & $-0,004$ & $-0,012$ \\
\hline & Medium-edu & $0,063^{* * *}$ & $0,105^{* \star *}$ & $0,100 * * *$ & $-0,037^{* * *}$ & $-0,090 * * *$ & $-0,074^{* *}$ & $-0,035^{* *}$ & $-0,010$ & $-0,031 * *$ & $-0,037^{\star * *}$ & $-0,010$ \\
\hline & Low-edu & 0,015 & $0,059^{* \star \star}$ & $-0,008$ & $-0,040^{* * *}$ & $-0,025 * \star \star *$ & $-0,053 * *$ & $-0,020 * *$ & $-0,016$ & $-0,054 * \star *$ & $-0,029 * * *$ & $-0,007$ \\
\hline \multicolumn{2}{|l|}{ Capital } & $-0,090 * * *$ & 0,000 & $1,071 * * *$ & $0,240 * * *$ & $-0,183^{* * *}$ & $-0,297^{* *}$ & $-0,211^{* * *}$ & $-0,206$ ** & $-0,228 * * *$ & $-0,077 * *$ & $-0,249 * * *$ \\
\hline \multicolumn{2}{|l|}{ Land } & $0,107 * *$ & $-0,019$ & $-0,503^{* * *}$ & $-0,165 * * *$ & $-0,046$ & 0,016 & $-0,177^{* * *}$ & $-0,007$ & $-0,096^{* \star *}$ & $-0,160^{* * *}$ & $-0,080^{* * *}$ \\
\hline \multicolumn{13}{|c|}{ Wald test } \\
\hline \multicolumn{2}{|c|}{$\begin{array}{l}\text { Temporal stability of Rybcz. Coeffs } \\
\text { p-value }\end{array}$} & $\begin{array}{r}12,62 \\
(0,000)\end{array}$ & $\begin{array}{r}27,63 \\
(0,000)\end{array}$ & $\begin{array}{l}465,03 \\
(0,000)\end{array}$ & $\begin{array}{r}77,71 \\
(0,000)\end{array}$ & $\begin{array}{l}319,66 \\
(0,000)\end{array}$ & $\begin{array}{r}21,11 \\
(0,000)\end{array}$ & $\begin{array}{l}178,44 \\
(0,000)\end{array}$ & $\begin{array}{r}66,97 \\
(0,000)\end{array}$ & $\begin{array}{l}159,53 \\
(0,000)\end{array}$ & $\begin{array}{l}331,50 \\
(0,000)\end{array}$ & $\begin{array}{r}54,56 \\
(0,000)\end{array}$ \\
\hline \multicolumn{2}{|l|}{ Sectors } & 12 & 13 & 14 & 15 & 16 & 17 & 18 & 19 & 20 & 21 & \\
\hline \multicolumn{2}{|c|}{ Absolute Prediction error } & 5,525 & 3,357 & 2,503 & 1,800 & 2,629 & 1,659 & 2,414 & 1,260 & 0,822 & 2,694 & \\
\hline \multicolumn{13}{|l|}{ Beta-coefficients } \\
\hline \multirow[t]{3}{*}{ Native work } & High-edu & 0,034 * & 0,043 * & $-0,052$ & 0,020 & $-0,058$ * & $0,058^{* * *}$ & $0,220 * * *$ & 0,069 *** & 0,007 & 0,064 & \\
\hline & Medium-edu & 0,057 ** & $-0,082$ ** & $-0,523^{* * *}$ & $0,075^{* *}$ & $-0,087^{* *}$ & $0,084^{* * *}$ & 0,056 & $-0,046$ & $0,084^{* * *}$ & 0,000 & \\
\hline & Low-edu & $-0,001$ & $-0,038 * *$ & $-0,489 * * *$ & $0,081^{* * *}$ & $-0,016$ & 0,049 *** & 0,043 & 0,010 & $0,101^{* * *}$ & $0,145^{* * *}$ & \\
\hline \multirow[t]{3}{*}{ Immigrant work } & High-edu & 0,010 & $0,045^{* \star *}$ & $-0,073^{* *}$ & $-0,009$ & $-0,010$ & $0,035^{* *}$ & $-0,011$ & 0,005 & $0,017^{*}$ & 0,049 ** & \\
\hline & Medium-edu & $-0,008$ & $-0,058^{* * *}$ & 0,021 & $-0,038$ * & $-0,041$ ** & $-0,082 * * *$ & $-0,003$ & 0,050 ** & 0,020 * & $-0,074^{* * *}$ & \\
\hline & Low-edu & 0,001 & $-0,004$ & 0,022 & 0,019 & 0,010 & $-0,004$ & $0,071^{* * *}$ & 0,024 * & $-0,002$ & 0,032 & \\
\hline \multicolumn{2}{|l|}{ Capital } & $-0,236 * * *$ & $-0,309 * * *$ & 0,328 ** & $-0,206^{\star \star *}$ & $-0,046$ & $-0,287^{* * *}$ & $-0,314 * * *$ & $0,303^{* * *}$ & $0,308^{* * *}$ & $-0,517^{* * *}$ & \\
\hline \multicolumn{2}{|l|}{ Land } & $-0,063 * *$ & $-0,022$ & 0,432 ** & $-0,139 * * *$ & $-0,036$ & $-0,095 * *$ & $0,224^{* * *}$ & $0,117^{* * *}$ & $0,103^{* * *}$ & $-0,062$ & \\
\hline \multicolumn{13}{|c|}{ Wald test } \\
\hline \multicolumn{2}{|c|}{$\begin{array}{l}\text { Temporal stability of Rybcz. Coeffs } \\
\text { p-value }\end{array}$} & $\begin{array}{r}16,98 \\
(0,000)\end{array}$ & $\begin{array}{r}76,55 \\
(0,000)\end{array}$ & $\begin{array}{r}9,42 \\
(0,000)\end{array}$ & $\begin{array}{r}69,19 \\
(0,000)\end{array}$ & $\begin{array}{r}85,90 \\
(0,000)\end{array}$ & $\begin{array}{r}44,32 \\
(0,000)\end{array}$ & $\begin{array}{r}81,38 \\
(0,000)\end{array}$ & $\begin{array}{l}125,68 \\
(0,000)\end{array}$ & $\begin{array}{r}35,94 \\
(0,000)\end{array}$ & $\begin{array}{l}201,09 \\
(0,000)\end{array}$ & \\
\hline
\end{tabular}

Notes: ${ }^{1}$ Sector classification according to TableA-1. The model specification includes period-varying dummy variables. $* * *, * *, *$ significant at $1 \%, 5 \%$ and $10 \%$ respectively. Wald test for the null of temporal stability of coefficients. 
Table 4. Hypotheses Tests for Equality in the Marginal Effects of Native and Foreign Actives by Education Categories.

\begin{tabular}{|c|c|c|c|c|}
\hline & Sector & Hig-edu. & Medium-edu. & Low-edu \\
\hline 1 & Agriculture & $\begin{array}{c}0,33 \\
(0,5672)\end{array}$ & $\begin{array}{c}4,5 \\
(0,0358)\end{array}$ & $\begin{array}{c}0,04 \\
(0,8427)\end{array}$ \\
\hline 2 & Extractive energy & $\begin{array}{c}1,1 \\
(0,2945)\end{array}$ & $\begin{array}{c}5,94 \\
(0,0148)\end{array}$ & $\begin{array}{c}9,04 \\
(0,0026)\end{array}$ \\
\hline 3 & Electricity, gas and water & $\begin{array}{c}1,43 \\
(0,2323)\end{array}$ & $\begin{array}{c}0,57 \\
(0,4496)\end{array}$ & $\begin{array}{c}8,24 \\
(0,0041)\end{array}$ \\
\hline 4 & Food, beberages and tobacco & $\begin{array}{c}0,14 \\
(0,7093)\end{array}$ & $\begin{array}{c}24,32 \\
(0,000)\end{array}$ & $\begin{array}{c}55,69 \\
(0,000)\end{array}$ \\
\hline 5 & Textiles, clothing, leather, fur & $\begin{array}{c}0,72 \\
(0,3966)\end{array}$ & $\begin{array}{c}75,13 \\
(0,000)\end{array}$ & $\begin{array}{c}9,71 \\
(0,0018)\end{array}$ \\
\hline 6 & Wood products, excl. Furniture & $\begin{array}{c}1,59 \\
(0,2072)\end{array}$ & $\begin{array}{c}11,34 \\
(0,0008)\end{array}$ & $\begin{array}{c}6,62 \\
(0,0101)\end{array}$ \\
\hline 7 & Paper, printing \& publishing & $\begin{array}{c}4,15 \\
(0,0417)\end{array}$ & $\begin{array}{c}10,83 \\
(0,001)\end{array}$ & $\begin{array}{c}5,03 \\
(0,0249)\end{array}$ \\
\hline 8 & Chemical products & $\begin{array}{c}0,25 \\
(0,6145)\end{array}$ & $\begin{array}{c}3,43 \\
(0,0638)\end{array}$ & $\begin{array}{c}2,44 \\
(0,1179)\end{array}$ \\
\hline 9 & Plastic \& rubber & $\begin{array}{c}0,82 \\
(0,3648)\end{array}$ & $\begin{array}{c}6,84 \\
(0,0089)\end{array}$ & $\begin{array}{c}35,68 \\
(0,000)\end{array}$ \\
\hline 10 & $\begin{array}{l}\text { Metal basic and other non-metallic } \\
\text { mineral prod. }\end{array}$ & $\begin{array}{c}0,15 \\
(0,6988)\end{array}$ & $\begin{array}{c}38,64 \\
(0,000)\end{array}$ & $\begin{array}{c}28,35 \\
(0,000)\end{array}$ \\
\hline 11 & $\begin{array}{l}\text { Mechanical \& Electric and } \\
\text { electronic equip. }\end{array}$ & $\begin{array}{c}1,53 \\
(0,2162)\end{array}$ & $\begin{array}{c}3,88 \\
(0,0489)\end{array}$ & $\begin{array}{c}1,52 \\
(0,2179)\end{array}$ \\
\hline 12 & Transport equipment & $\begin{array}{c}0,25 \\
(0,6194)\end{array}$ & $\begin{array}{c}1,53 \\
(0,2161)\end{array}$ & $\begin{array}{c}0,01 \\
(0,9206)\end{array}$ \\
\hline 13 & Miscellaneous & $\begin{array}{c}6,88 \\
(0,0087)\end{array}$ & $\begin{array}{c}8,9 \\
(0,0029)\end{array}$ & $\begin{array}{c}0,01 \\
(0,9249)\end{array}$ \\
\hline 14 & Building & $\begin{array}{c}2,62 \\
(0,1082)\end{array}$ & $\begin{array}{c}11,46 \\
(0,0009)\end{array}$ & $\begin{array}{c}4,66 \\
(0,0327)\end{array}$ \\
\hline 15 & Reparation and commerce & $\begin{array}{c}0,5 \\
(0,4789)\end{array}$ & $\begin{array}{c}6,27 \\
(0,0123)\end{array}$ & $\begin{array}{c}0,7 \\
(0,4016)\end{array}$ \\
\hline 16 & Hotels & $\begin{array}{c}0,05 \\
(0,8274)\end{array}$ & $\begin{array}{c}3,72 \\
(0,0537)\end{array}$ & $\begin{array}{c}0,95 \\
(0,329)\end{array}$ \\
\hline 18 & Transport \& communi.serv. & $\begin{array}{c}2,26 \\
(0,1326)\end{array}$ & $\begin{array}{c}24,65 \\
(0,000)\end{array}$ & $\begin{array}{c}0,37 \\
(0,5448)\end{array}$ \\
\hline 18 & Financial services & $\begin{array}{c}3,21 \\
(0,073)\end{array}$ & $\begin{array}{c}0,12 \\
0,7254)\end{array}$ & $\begin{array}{c}7,83 \\
0,0051)\end{array}$ \\
\hline 19 & Renting and business services & $\begin{array}{c}0,2 \\
(0,6566)\end{array}$ & $\begin{array}{c}8,7 \\
(0,0032)\end{array}$ & $\begin{array}{c}3,22 \\
(0,0727)\end{array}$ \\
\hline 20 & $\begin{array}{l}\text { Education, health and other } \\
\text { services }\end{array}$ & $\begin{array}{c}2,48 \\
(0,1153)\end{array}$ & $\begin{array}{c}0,26 \\
(0,6123)\end{array}$ & $\begin{array}{c}1,65 \\
(0,1996)\end{array}$ \\
\hline 21 & Household services & $\begin{array}{c}2,74 \\
(0,0978) \\
\end{array}$ & $\begin{array}{c}6,8 \\
(0,0091) \\
\end{array}$ & $\begin{array}{c}0,95 \\
(0,3286) \\
\end{array}$ \\
\hline
\end{tabular}

Note: Wald tests. P-values in parentheses. 
Table 5. Decomposition of Output Change between 1996 and 2005

\begin{tabular}{|c|c|c|c|}
\hline & Techniques & Factor Endowments & Residual \\
\hline Sector & $\bar{V}\left(\hat{R}_{i}^{t}-\hat{R}_{i}^{t-n}\right)$ & $\left(V^{t}-V^{t-n}\right) \hat{\bar{R}}_{i}$ & $\overline{\left(\hat{\varepsilon}_{i}^{t}-\hat{\varepsilon}_{i}^{t-n}\right)}$ \\
\hline 1 & 47,5 & 6,7 & 45,8 \\
\hline 2 & 50,4 & 0,9 & 48,7 \\
\hline 3 & 44,5 & 8,9 & 46,5 \\
\hline 4 & 40,8 & 14,7 & 44,5 \\
\hline 5 & 49,9 & 9,8 & 40,3 \\
\hline 6 & 46,2 & 29,8 & 24,0 \\
\hline 7 & 50,8 & 2,0 & 47,2 \\
\hline 8 & 52,1 & 3,8 & 44,1 \\
\hline 9 & 51,1 & 1,9 & 47,0 \\
\hline 10 & 41,2 & 8,5 & 50,3 \\
\hline 11 & 53,8 & 1,8 & 44,4 \\
\hline 12 & 42,8 & 8,9 & 48,3 \\
\hline 13 & 47,3 & 20,5 & 32,2 \\
\hline 14 & 31,9 & 57,4 & 10,8 \\
\hline 15 & 37,6 & 5,0 & 57,4 \\
\hline 16 & 26,9 & 18,9 & 54,1 \\
\hline 17 & 36,1 & 11,4 & 52,4 \\
\hline 18 & 47,7 & 2,3 & 50,0 \\
\hline 19 & 47,8 & 2,2 & 50,0 \\
\hline 20 & 46,8 & 3,1 & 50,1 \\
\hline 21 & 47,0 & 3,2 & 49,8 \\
\hline Mean & 44,8 & 10,6 & 44,7 \\
\hline
\end{tabular}

Note: Values indicate the cross-region average percentage contributions of the three effects in terms of relative magnitudes, normalised to sum to 100 percent (aside from rounding). 
Table 6. Alternative Decomposition of Output Change between 1996 and 2005

\begin{tabular}{|c|c|c|c|c|}
\hline & Techniques & Factor Endowments & Regional Scale & Residual \\
\hline Sector & $\bar{V}\left(\hat{R}_{i}^{t}-\hat{R}_{i}^{t-n}\right)$ & $\left(V^{t}-V^{t-n}\right) \hat{\bar{R}}_{i}$ & $\left(Q^{t}-Q^{t-n}\right) \hat{\bar{\varepsilon}}_{i}$ & $\left(\hat{\varepsilon}_{i}^{t}-\hat{\varepsilon}_{i}^{t-n}\right)$ \\
\hline 1 & 42,9 & 3,2 & 8,2 & 45,7 \\
\hline 2 & 40,7 & 1,2 & 4,9 & 53,1 \\
\hline 3 & 55,6 & 11,1 & 14,4 & 18,8 \\
\hline 4 & 19,8 & 0,9 & 22,0 & 57,4 \\
\hline 5 & 32,2 & 8,5 & 11,0 & 48,4 \\
\hline 6 & 29,8 & 55,0 & 7,7 & 7,5 \\
\hline 7 & 49,4 & 0,5 & 35,6 & 14,4 \\
\hline 8 & 36,6 & 3,8 & 38,1 & 21,5 \\
\hline 9 & 44,4 & 7,5 & 8,0 & 40,1 \\
\hline 10 & 10,9 & 5,7 & 32,0 & 51,4 \\
\hline 11 & 35,8 & 12,4 & 19,7 & 32,2 \\
\hline 12 & 29,0 & 13,0 & 17,4 & 40,5 \\
\hline 13 & 11,7 & 17,6 & 28,8 & 41,9 \\
\hline 14 & 13,2 & 10,4 & 26,3 & 50,1 \\
\hline 15 & 15,1 & 6,8 & 54,3 & 23,7 \\
\hline 16 & 17,6 & 3,0 & 40,6 & 38,8 \\
\hline 17 & 25,6 & 9,2 & 35,2 & 30,0 \\
\hline 18 & 40,8 & 9,3 & 0,1 & 49,9 \\
\hline 19 & 40,8 & 9,2 & 0,1 & 49,9 \\
\hline 20 & 40,8 & 8,8 & 1,9 & 48,5 \\
\hline 21 & 39,1 & 9,3 & 0,3 & 51,4 \\
\hline Mean & 32,0 & 9,8 & 19,4 & 38,8 \\
\hline
\end{tabular}

Note: Values indicate the cross-region average percentage contributions of the three effects normalised to sum to 100 percent (aside from rounding). 
Table A-1. Geographic units and Sector classification.

\begin{tabular}{|c|c|}
\hline \multicolumn{2}{|l|}{ Geographic unit } \\
\hline Provinces (NUTS 3) & Autonomous Communities (NUTS 2) \\
\hline \multicolumn{2}{|l|}{ Period } \\
\hline 1996-2005 & $1996-2005$ \\
\hline $\begin{array}{l}\text { Sectors } \\
\text { S-5 }\end{array}$ & S-21 \\
\hline 1. Agriculture & 1 Agriculture \\
\hline 2. Energy & $\begin{array}{l}2 \text { Extractive energy and other energetic minerals, oil and } \\
\text { nuclear } \\
3 \text { Electricity, gas and water }\end{array}$ \\
\hline 3. Manufactures & $\begin{array}{l}4 \text { Food, drink and tobacco } \\
5 \text { Textiles, clothing, leather, fur } \\
6 \text { Wood products, excl. furniture } \\
7 \text { Paper, printing and publishing } \\
8 \text { Chemical products } \\
9 \text { Plastic, rubber } \\
10 \text { Metal basic industries and other non-metallic mineral } \\
\text { products } \\
11 \text { Mechanical mach. \& electric and electronic equipment } \\
12 \text { Transport equipment } \\
13 \text { Miscellaneous }\end{array}$ \\
\hline 4. Building & 14 Building \\
\hline 5. Services & $\begin{array}{l}15 \text { Reparation and commerce } \\
16 \text { Hotels } \\
17 \text { Transport and communication services } \\
18 \text { Financial services } \\
19 \text { Renting and business services } \\
20 \text { Education, health and other services } \\
21 \text { Household services }\end{array}$ \\
\hline
\end{tabular}


Table A-2. Coefficient Estimates. GLS-SUR estimates. (1996-2005).

\begin{tabular}{|c|c|c|c|c|c|c|}
\hline \multicolumn{2}{|c|}{ Time dummies. Model (4a) } & AGRI & ENER & INDUS & CONST & SERV \\
\hline \multirow[t]{6}{*}{ Native work } & High-edu & $0 ' 777$ & $4^{\prime} 663^{\star \star *}$ & $-2 ' 865$ & $3^{\prime} 498^{\star * *}$ & $-8^{\prime} 858^{*}$ \\
\hline & & $\left(1^{\prime} 655\right)$ & $\left(1^{\prime} 002\right)$ & $\left(4^{\prime} 287\right)$ & $\left(1^{\prime} 137\right)$ & $\left(4^{\prime} 691\right)$ \\
\hline & Medium-edu & $1^{\prime} 990^{* \star *}$ & $00^{\prime} 081$ & $-12^{\prime} 899^{\star * *}$ & $1^{\prime} 535^{\star \star *}$ & $8^{\prime} 777^{* \star *}$ \\
\hline & & $\left(0^{\prime} 645\right)$ & $(0 ' 365)$ & $(1 ' 597)$ & $\left(0^{\prime} 422\right)$ & $\left(1^{\prime} 710\right)$ \\
\hline & Low-edu & $2^{\prime} 971^{* \star *}$ & $1^{\prime} 363^{\star \star \star}$ & $-0 ' 653$ & $0 ' 183$ & $-2^{\prime} 030$ \\
\hline & & $(0 ' 583)$ & $\left(0^{\prime} 333\right)$ & $(1 ' 312)$ & (0'393) & $(1 ' 383)$ \\
\hline \multirow[t]{6}{*}{ Immigrant work } & High-edu & $-32^{\prime} 109^{\star \star \star}$ & $-9 ' 530$ & $-87^{\prime} 806^{\star \star *}$ & $-4 ' 469$ & $137^{\prime} 969^{\star \star \star}$ \\
\hline & & $(10 ' 304)$ & $\left(6^{\prime} 478\right)$ & $(28 ' 439)$ & $\left(6^{\prime} 771\right)$ & $(29 ' 602)$ \\
\hline & Medium-edu & $-2 ' 737$ & 0'950 & $-46^{\prime} 177^{\star \star *}$ & $6 \prime 091^{* *}$ & $37^{\prime} 106^{\star * *}$ \\
\hline & & $\left(3^{\prime} 796\right)$ & (2'389) & $\left(9^{\prime} 997\right)$ & $\left(2^{\prime} 490\right)$ & $\left(10^{\prime} 464\right)$ \\
\hline & Low-edu & $25^{\prime} 773^{\star \star \star}$ & $-2 ' 514$ & $18 ' 624$ & $-7^{\prime} 553^{\star *}$ & $-31^{\prime} 364^{\star \star}$ \\
\hline & & $\left(4^{\prime} 638\right)$ & (2'693) & $(12 ' 536)$ & $\left(2^{\prime} 975\right)$ & $(12 ' 919)$ \\
\hline \multirow{2}{*}{\multicolumn{2}{|c|}{ Capital }} & $0 ' 004$ & $0^{\prime} 007^{\star \star \star}$ & $0^{\prime} 027^{\star \star \star}$ & $00^{\prime} 011^{\star \star *}$ & $-0,051^{\star * *}$ \\
\hline & & $\left(0^{\prime} 003\right)$ & $\left(0^{\prime} 002\right)$ & $\left(0^{\prime} 009\right)$ & $\left(0^{\prime} 002\right)$ & $\left(0^{\prime} 010\right)$ \\
\hline \multirow{2}{*}{\multicolumn{2}{|c|}{ Land }} & $0^{\prime} 420^{\star * *}$ & $-0{ }^{\prime} 015$ & $-0^{\prime} 326^{\star \star *}$ & 0'012 & $-0,102$ \\
\hline & & $\left(0^{\prime} 029\right)$ & $(0,017)$ & $(0,073)$ & $\left(0^{\prime} 018\right)$ & $(0,076)$ \\
\hline \multicolumn{2}{|c|}{ Time \& Regional dummies. Model (4b) } & AGRI & ENER & INDUS & CONST & SERV \\
\hline \multirow[t]{6}{*}{ Native work } & High-edu & $-1^{\prime} 504^{*}$ & $2^{\prime} 509^{\star \star \star}$ & $1 ' 161$ & $-1 ' 051$ & 0 0'383 \\
\hline & & $(0 ' 847)$ & $\left(0^{\prime} 697\right)$ & $\left(1^{\prime} 208\right)$ & $(0 ' 881)$ & $\left(1^{\prime} 286\right)$ \\
\hline & Medium-edu & $0 ' 522^{*}$ & $1^{\prime} 111^{\star * *}$ & $1^{\prime} 825^{\star \star \star}$ & $-2 ' 931^{\star \star *}$ & $1^{\prime} 617^{\star \star *}$ \\
\hline & & $\left(0^{\prime} 268\right)$ & $\left(0^{\prime} 234\right)$ & $(0 ' 399)$ & $\left(0^{\prime} 270\right)$ & $\left(0^{\prime} 417\right)$ \\
\hline & Low-edu & $1^{\prime} 552^{\star \star \star}$ & $1^{\prime} 337^{\star \star \star}$ & $0 ' 187$ & $-2 ' 207^{\star \star \star}$ & $1^{\prime} 053^{\star \star \star}$ \\
\hline & & $\left(0^{\prime} 152\right)$ & $\left(0^{\prime} 132\right)$ & (0'207) & $\left(0^{\prime} 161\right)$ & (0'207) \\
\hline \multirow[t]{6}{*}{ Immigrant work } & High-edu & 2'404 & $-2 ' 370$ & $-3 ' 902$ & $-2 ' 789$ & 1'975 \\
\hline & & $(2 ' 865)$ & $\left(2^{\prime} 483\right)$ & $\left(4^{\prime} 118\right)$ & (2'865) & $\left(4^{\prime} 352\right)$ \\
\hline & Medium-edu & $1 ' 510$ & $1^{\prime} 606^{*}$ & $-2 ' 636^{*}$ & $0 ' 641$ & $-0 ' 373$ \\
\hline & & (1'013) & (0'902) & $(1 ' 424)$ & $\left(0^{\prime} 990\right)$ & $\left(1^{\prime} 468\right)$ \\
\hline & Low-edu & $-3^{\prime} 484^{* \star}$ & $2^{\prime} 212^{\star \star}$ & $-2 ' 134$ & $0^{\prime} 283$ & $9^{\prime} 526^{\star * *}$ \\
\hline & & (1'391) & (1'103) & (1'977) & (1'533) & (2'003) \\
\hline \multirow{2}{*}{\multicolumn{2}{|c|}{ Capital }} & $-0 \prime 007^{\star \star \star}$ & $0^{\prime} 005^{\star \star \star}$ & $-0^{\prime} 019^{\star \star \star}$ & $0^{\prime} 011^{\star * *}$ & $0^{\prime} 007^{\star \star \star}$ \\
\hline & & $\left(0^{\prime} 002\right)$ & $\left(0^{\prime} 001\right)$ & $\left(0^{\prime} 002\right)$ & $\left(0^{\prime} 002\right)$ & $\left(0^{\prime} 002\right)$ \\
\hline \multirow{2}{*}{\multicolumn{2}{|c|}{ Land }} & 0'031 & $-0^{\prime} 105^{\star \star *}$ & $-0^{\prime} 235^{\star \star *}$ & $0^{\prime} 144^{* * *}$ & $0^{\prime} 192^{\star \star *}$ \\
\hline & & $\left(0^{\prime} 026\right)$ & $\left(0^{\prime} 021\right)$ & $\left(0^{\prime} 034\right)$ & $\left(0^{\prime} 025\right)$ & $\left(0^{\prime} 034\right)$ \\
\hline \multicolumn{2}{|c|}{ Time-varying Reg. dum. Model (4c) } & AGRI & ENER & INDUS & CONST & SERV \\
\hline \multirow[t]{6}{*}{ Native work } & High-edu & $-0 ' 218$ & $2^{\prime} 004^{* \star *}$ & $0 ' 264$ & $-1 ' 092^{* *}$ & $1 ' 455$ \\
\hline & & $\left(0^{\prime} 474\right)$ & $\left(0^{\prime} 433\right)$ & $\left(0^{\prime} 661\right)$ & $\left(0^{\prime} 489\right)$ & $\left(0^{\prime} 914\right)$ \\
\hline & Medium-edu & $1^{\prime} 134^{\star \star \star}$ & $0^{\prime} 788^{\star \star \star}$ & $1^{\prime} 572^{\star \star *}$ & $-3^{\prime} 095^{\star \star \star}$ & 0 037 \\
\hline & & $(0 ' 187)$ & $(0 ' 187)$ & $\left(0^{\prime} 267\right)$ & $(0 ' 177)$ & $(0 ' 380)$ \\
\hline & Low-edu & $1^{\prime} 326^{\star \star *}$ & $1^{\prime} 926^{\star * *}$ & $0^{\prime} 709^{\star \star *}$ & $-2^{\prime} 212^{\star \star *}$ & $1^{\prime} 298^{\star * *}$ \\
\hline & & $\left(0^{\prime} 111\right)$ & $\left(0^{\prime} 125\right)$ & $\left(0^{\prime} 157\right)$ & $\left(0^{\prime} 114\right)$ & $\left(0^{\prime} 220\right)$ \\
\hline \multirow[t]{6}{*}{ Immigrant work } & High-edu & $-1 ' 434$ & $-1 ' 100$ & $4^{\prime} 322^{*}$ & $-6^{\prime} 516^{\star * \star}$ & 1'803 \\
\hline & & (1'619) & $(1 ' 580)$ & $(2 ' 383)$ & (1'655) & $\left(3^{\prime} 286\right)$ \\
\hline & Medium-edu & $3^{\prime} 069^{\star \star \star}$ & $2^{\prime} 426^{\star \star \star}$ & $-1 ' 956^{*}$ & 0'591 & $-0 ' 011$ \\
\hline & & $\left(0^{\prime} 700\right)$ & (0'689) & $\left(1^{\prime} 026\right)$ & (0'694) & (1'297) \\
\hline & Low-edu & $1^{\prime} 988^{*}$ & 0'877 & $-2^{\prime} 494^{*}$ & 0'562 & $6^{\prime} 419^{* * *}$ \\
\hline & & (1'053) & $(0 ' 964)$ & $\left(1^{\prime} 443\right)$ & $\left(1^{\prime} 042\right)$ & (1'849) \\
\hline \multirow{2}{*}{\multicolumn{2}{|c|}{ Capital }} & $-0^{\prime} 007^{* * *}$ & $0^{\prime} 007^{* \star *}$ & $-0^{\prime} 019^{* \star \star}$ & $0^{\prime} 013^{* * *}$ & 0'002 \\
\hline & & $(0 ' 001)$ & $(0 ' 001)$ & (0'002) & $(0,001)$ & (0'002) \\
\hline \multirow{2}{*}{\multicolumn{2}{|c|}{ Land }} & $00^{\prime} 061^{* *}$ & $-0 ' 034$ & $-0^{\prime} 276^{\star \star *}$ & $0^{\prime} 157^{\star \star *}$ & $0^{\prime} 259^{\star * *}$ \\
\hline & & $\left(0^{\prime} 026\right)$ & $\left(0^{\prime} 024\right)$ & $\left(0^{\prime} 030\right)$ & $\left(0^{\prime} 021\right)$ & $\left(0^{\prime} 040\right)$ \\
\hline \multicolumn{7}{|c|}{ Homogeneity of Rybzc coeffs across activity branches belonging to the same sector. Model (4c) } \\
\hline \multirow{2}{*}{\multicolumn{2}{|c|}{$\begin{array}{l}\text { Wald test }(\mathrm{df}) \\
\text { P-value }\end{array}$}} & - & 454 '3 (8) & $1026,7(72)$ & - & $1128,7(48)$ \\
\hline & & - & $(0,000)$ & $(0,000)$ & - & $(0,000)$ \\
\hline
\end{tabular}

***, **,* significant at $1 \%, 5 \%$ and $10 \%$ respectively Standard errors are in parentheses.

Wald test: P-values in parenthesis 
Table A-3. Coefficient Estimates. GLS and SUR estimates. (1996-2005). [Continues]

\begin{tabular}{|c|c|c|c|c|c|c|c|c|c|c|c|c|c|c|c|c|c|c|c|c|c|c|}
\hline Regional dummies & & 1 & 2 & 3 & 4 & 5 & 6 & 7 & 8 & 9 & 10 & 11 & 12 & 13 & 14 & 15 & 16 & 17 & 18 & 19 & 20 & 21 \\
\hline \multirow[t]{5}{*}{ Native work } & High-edu & $\begin{array}{l}-0^{\prime} 7424 \\
112778)\end{array}$ & $1^{\prime} 468^{* *}$ & $\begin{array}{l}0^{\prime} 612 \\
0^{\prime} 732 ?\end{array}$ & $\begin{array}{l}-0^{\prime} 425 \\
-4398\end{array}$ & $\begin{array}{l}-0^{\prime} 001 \\
\end{array}$ & $\begin{array}{l}-0^{\prime} 628 \\
\end{array}$ & $\begin{array}{l}-0^{\prime} 055 \\
-055\end{array}$ & $\begin{array}{l}-200 \\
-0,200\end{array}$ & 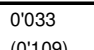 & $\begin{array}{l}-2444 \\
-02263\end{array}$ & $\begin{array}{ll}0 \\
0\end{array}$ & $\begin{array}{l}0^{\prime} 655 \\
06514\end{array}$ & $\begin{array}{l}0^{\prime} 014 \\
\left.0^{\prime} 1257\right)\end{array}$ & $\begin{array}{l}-0^{\prime} 136 \\
\end{array}$ & $\begin{array}{l}0.997 \\
\end{array}$ & $\begin{array}{l}-0^{\prime} 791 \\
\end{array}$ & $\begin{array}{l}0^{\prime} 667 \\
\left.60^{\prime} 465\right)\end{array}$ & $1^{\prime \prime 522^{*+*}}$ & $\begin{array}{l}1 ' 028 \\
02909\end{array}$ & $\begin{array}{l}0^{\prime} 198 \\
(1987)\end{array}$ & $\begin{array}{l}0^{\prime} 026 \\
0^{\prime}{ }^{\prime}\end{array}$ \\
\hline & Medium-edu & 0.4004 & $0718^{* * t}$ & $0^{\prime} 402^{*}$ & 0 & $\begin{array}{l}-0^{\prime} 069 \\
\end{array}$ & $\begin{array}{l}0^{\prime} 026 \\
-26\end{array}$ & $0^{\prime} 210^{* * *+}$ & 0 & 0 & $0^{\prime} 249^{* *}$ & 0 & 0 & $-0^{\prime} 044$ & $-2^{2} 843^{+* x+}$ & $-0^{\prime} 011$ & $-0^{\prime} 220$ & 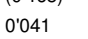 & $\begin{array}{l}-0^{2} 256^{*} \\
\end{array}$ & $-0^{\prime} 474^{*}$ & 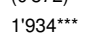 & $0807^{* * *+}$ \\
\hline & & $\left(0^{\prime} 3711\right)$ & (0'206) & $\left(0^{\prime} 227\right)$ & $\left(0^{\prime} 120\right)$ & $\left(0^{\prime} 094\right)$ & $\left(0^{\prime} 132\right)$ & $\left(0^{\prime} 059\right)$ & $\left(0^{\prime} 062\right)$ & $\left(0^{\prime} 034\right)$ & $\left(0^{\prime} 113\right)$ & $\left(0^{\prime} 091\right)$ & $\left(0^{\prime} 140\right)$ & $\left(0^{\prime} 037\right)$ & $\left(0^{\prime} 305\right)$ & '268) & (0'319) & $\left(0^{\prime} 142\right)$ & $\left(0^{\prime} 149\right)$ & (0'261) & $\left(0^{\prime 2} 269\right)$ & $\left(0^{\prime} 030\right)$ \\
\hline & Low-edu & $1^{15489^{*+*}}$ & 0'119 & $1^{1} 414^{4 * * *}$ & $0^{\prime} 426^{* * *}$ & $0^{\prime} 055$ & 0'051 & $-0^{\prime} 027$ & $-0^{\prime} 090^{\star \star \star}$ & $-0^{\prime} 037^{* *}$ & 0'007 & $-0^{\prime} 053$ & $0^{\prime} 015$ & $-0^{\prime} 018$ & $-2^{\prime} 164^{* * *}$ & $0,367^{*+*}$ & $-0^{\prime} 532^{* * *}$ & $0^{\prime 2} 254^{* * *}$ & $-0^{\prime} 013$ & $0^{\prime} 037$ & $0^{\prime} 904^{* * *}$ & $0^{\prime} 140^{* * *}$ \\
\hline & & $\left(0^{\prime} 1890\right)$ & $\left(0^{\prime} 108\right)$ & $\left(0^{\prime} 114\right)$ & $\left(0^{\prime} 059\right)$ & $\left(0^{\prime} 048\right)$ & $\left(0^{\prime} 065\right)$ & $\left(0^{\prime} 029\right)$ & (0'030) & $\left(0^{\prime} 018\right)$ & $\left(0^{\prime} 055\right)$ & $\left(0^{\prime} 046\right)$ & $\left(0^{\prime} 076\right)$ & $\left(0^{\prime} 019\right)$ & $\left(0^{\prime} 155\right)$ & $\left(0^{\prime} 133\right)$ & $\left(0^{\prime} 148\right)$ & $\left(0^{\prime} 073\right)$ & $\left(0^{\prime} 075\right)$ & $\left(0^{\prime} 133\right)$ & $\left(0^{\prime} 139\right)$ & $\left(0^{\circ} 017\right)$ \\
\hline \multirow[t]{6}{*}{ Immigrant work } & High-edu & $5^{\prime} 6081$ & -1797 & 0,553 & 1'326 & $-1^{\prime} 891^{*}$ & $-3^{\prime} 450^{* *}$ & $1^{\prime 381^{* *}}$ & $-0^{\prime} 179$ & $-0^{\prime} 138$ & $-2 \cdot 566^{* *}$ & $-0^{\prime} 166$ & $1 ' 888$ & 0'262 & $-1^{1} 579$ & $-1 ' 547$ & $0^{\prime} 023$ & 2576 & $1^{\prime} 650$ & -0'280 & $1^{\prime} 480$ & $1^{\prime 1} 158^{* * *}$ \\
\hline & & $\left(4^{\prime} 0659\right)$ & (2'265) & (2'463) & (1'296) & $\left(1^{\prime} 040\right)$ & $\left(1^{\prime} 355\right)$ & $\left(0^{\prime} 653\right)$ & $\left(0^{\prime} 647\right)$ & $(0 ' 352)$ & $\left(1^{\prime} 186\right)$ & $\left(1^{\prime} 057\right)$ & $(1 ' 507)$ & $\left(0^{\prime} 415\right)$ & $\left(3^{\prime} 342\right)$ & $\left(2^{\prime} 914\right)$ & (3'245) & $(1598)$ & $\left(1^{\prime} 619\right)$ & $\left(2^{\prime} 907\right)$ & (2'800) & $\left(0^{\prime} 325\right)$ \\
\hline & Medium-edu & 0'8007 & $3781^{* * *}$ & $-2^{2} 113^{* *}$ & $-0^{\prime} 248$ & $-1^{\prime} 817^{* * \star}$ & $-1^{\prime} 861^{* * *}$ & $-0,503^{* *}$ & 0'015 & $0^{\prime} 035$ & $-0^{\prime} 445$ & -0'004 & $-0^{\prime} 168$ & $-0^{0} 563^{\text {t*x}}$ & 17711 & & $-3^{3} 906^{* * *}$ & $-1^{\prime} 380^{* *}$ & 903 & $1^{1} 907^{*}$ & 1'384 & -0 '159 \\
\hline & & $\left(1^{\prime} 4010\right)$ & $\left(0^{\prime} 833\right)$ & $\left(0^{\prime} 832\right)$ & $\left(0^{\prime} 460\right)$ & $\left(0^{\prime} 357\right)$ & $\left(0^{\prime} 487\right)$ & $\left(0^{\prime} 226\right)$ & $\left(0^{\prime} 231\right)$ & $\left(0^{\prime} 121\right)$ & $\left(0^{\prime} 412\right)$ & $\left(0^{\prime} 354\right)$ & $\left(0^{\prime} 515\right)$ & $\left(0^{\prime} 140\right)$ & $\left(1^{\prime} 15\right)$ & $\left(0^{\prime} 997\right)$ & $\left(1^{\prime} 168\right)$ & $\left(0^{\prime} 541\right)$ & $\left(0^{\prime} 5661\right)$ & ('996) & (0'971) & $\left(0^{\prime} 112\right)$ \\
\hline & Low-edu & & $1 ' 849$ & $0 ' 791$ & $-3^{\prime} 846^{\star \star \star}$ & $-1^{\prime} 051^{* *}$ & $-1^{\prime} 327^{*}$ & $-0^{\prime} 268$ & $1^{1297^{* * * *}}$ & $-0^{\prime} 515^{* * * *}$ & $0^{\prime} 875$ & $0^{\prime} 611$ & $-0^{\prime} 244$ & $0^{\prime} 064$ & $2^{\prime 2} 202$ & $-3^{\prime} 707^{7 * *}$ & $7^{\prime} 112^{2+* t+}$ & $1 ' 014$ & $361^{* * *}$ & 2052 & $2^{\prime} 071$ & $0^{\prime} 427^{7 * *}$ \\
\hline & & (1'9315) & $\left(1^{\prime 167)}\right.$ & $\left(1^{\prime} 097\right)$ & $\left(0^{\prime} 697\right)$ & $\left(0^{\prime} 496\right)$ & $\left(0^{\prime} 680\right)$ & $\left(0^{\prime 2} 294\right)$ & $(0 ; 312)$ & $\left(0^{\prime} 175\right)$ & $\left(0^{\prime} 539\right)$ & $\left(0^{\prime} 484\right)$ & $\left(0^{\prime} 696\right)$ & $\left(0^{\prime 2} 203\right)$ & $\left(1^{\prime} 588\right)$ & $\left(1^{\prime} 416\right)$ & $\left(1^{\prime} 449\right)$ & $\left(0^{\prime} 724\right)$ & $\left(0^{\prime} 777\right)$ & (1'325) & $\left(1^{\prime} 367\right)$ & $\left(0^{\prime} 150\right)$ \\
\hline \multirow[t]{2}{*}{ Capital } & w1kap & $-0^{\prime} 0059^{* *}$ & $-0^{\prime} 004^{* *+x}$ & $0^{\prime} 009^{* * t+}$ & $-0^{\prime} 002^{* *}$ & $-0^{\prime} 001$ & $-0^{\prime} 001$ & $-0^{\prime} 001^{* *}$ & $-0^{\prime} 001^{* * * *}$ & $-0^{\prime} 001^{* * *}$ & $-0^{\prime} 000$ & $-0^{\prime} 002^{* *+x}$ & $-0^{\prime} 004^{* * * *}$ & $-0^{\prime} 001^{* * t}$ & $0^{\prime} 0103^{* * *}$ & $-0^{\prime} 007^{\star \star \star *}$ & $0^{\prime} 002$ & $-0^{\prime} 003^{t+x}$ & $-0^{\prime} 003^{* \star * *}$ & $0^{\prime} 010^{* * * *}$ & $0^{\prime} 015^{* * *}$ & $-0^{\prime} 001^{*+* x}$ \\
\hline & & $\left(0^{\prime} 0024\right)$ & $\left(0^{\prime} 001\right)$ & $\left(0^{\prime} 001\right)$ & $\left(0^{\prime} 001\right)$ & $\left(0^{\prime} 001\right)$ & $\left(0^{\prime} 001\right)$ & $\left(0^{\prime} 000\right)$ & $\left(0^{\prime} 000\right)$ & $\left(0^{\prime} 000\right)$ & $\left(0^{\prime} 001\right)$ & $\left(0^{\prime} 001\right)$ & $\left(0^{\prime} 001\right)$ & $\left(0^{\prime} 000\right)$ & $\left(0^{\prime} 00193\right)$ & $\left(0^{\prime} 002\right)$ & $\left(0^{\prime} 002\right)$ & $\left(0^{\prime} 001\right)$ & $\left(0^{\prime} 001\right)$ & $\left(0^{\prime} 002\right)$ & $\left(0^{\prime} 002\right)$ & $\left(0^{\prime} 000\right)$ \\
\hline \multirow[t]{2}{*}{ Land } & w1land & 0'0524 & $-0^{\prime} 052^{* *}$ & $-0^{\prime} 081^{* *+*}$ & $-0^{\prime} 075^{\star * *}$ & $0^{\prime} 014$ & $0^{\prime} 015$ & $-0^{\prime} 021^{* * *}$ & $0^{\prime} 010^{*}$ & $-0^{\prime} 012^{* * * t}$ & $-0^{\prime} 078^{\star \star \star *}$ & $-0^{\prime} 020^{* *}$ & $-0^{\prime} 031^{* *}$ & $-0^{\prime} 002$ & $0^{\prime} 113^{* \star *}$ & $-0^{\prime} 002$ & $0^{\prime} 042$ & $-0^{\prime} 007$ & $0,051^{1 * * *}$ & $0^{\prime} 027$ & $0^{\prime} 052^{* *}$ & $-0^{\prime} 005^{*}$ \\
\hline & & $\left(0^{\prime} 0335\right)$ & $\left(0^{\prime} 022\right)$ & $\left(0^{\prime} 020\right)$ & $\left(0^{\prime} 010\right)$ & $\left(0^{\prime} 009\right)$ & $\left(0^{\prime} 012\right)$ & $\left(0^{\prime} 005\right)$ & $\left(0^{\prime} 005\right)$ & $\left(0^{\prime} 003\right)$ & $\left(0^{\prime} 010\right)$ & $\left(0^{\prime} 008\right)$ & $\left(0^{\prime} 013\right)$ & $\left(0^{\prime} 003\right)$ & $\left(0^{\prime} 0276\right)$ & $\left(0^{\prime} 023\right)$ & $\left(0^{\prime} 027\right)$ & $\left(0^{\prime} 013\right)$ & $\left(0^{\prime} 014\right)$ & $\left(0^{\prime} 024\right)$ & $\left(0^{\prime} 026\right)$ & $\left(0^{\prime} 003\right)$ \\
\hline Akaike IC. & & $-8,12$ & $-9,37$ & $-9,37$ & $-10,53$ & $-10,67$ & $-10,03$ & $-11,76$ & $-11,64$ & $-12,88$ & $-10,66$ & $-10,75$ & $-10,17$ & $-12,63$ & $-8,52$ & $-8,79$ & $-8,64$ & $-10,08$ & $-9,99$ & $-8,88$ & $-8,85$ & $-13,23$ \\
\hline Time \& Regional dummies & & 1 & 2 & 3 & 4 & 5 & 6 & 7 & 8 & 9 & 10 & 11 & 12 & 13 & 14 & 15 & 16 & 17 & 18 & 19 & 20 & 21 \\
\hline \multirow{5}{*}{ Native work } & High-edu & $\begin{array}{l}-0^{0} 2189 \\
(12395)\end{array}$ & $\begin{array}{l}1^{\prime} 442^{\star *} \\
\left(0^{\prime} 673\right)\end{array}$ & $\begin{array}{l}0^{\prime} 543 \\
\left(0^{\prime} 730\right)\end{array}$ & $\begin{array}{l}-0^{\prime} 564 \\
\left(0^{\prime} 381\right)\end{array}$ & $\begin{array}{l}-0^{\prime} 028 \\
\left(0^{\prime} 300\right)\end{array}$ & $\begin{array}{l}-0^{\prime} 642 \\
\left(0^{\prime} 427\right)\end{array}$ & $\begin{array}{l}-0^{\prime} 034 \\
\left(0^{\prime} 202\right)\end{array}$ & $\begin{array}{l}-0^{\prime} 225 \\
\left.00^{\prime 2} 201\right)\end{array}$ & $\begin{array}{l}0^{\prime} 029 \\
0^{\prime} 1099\end{array}$ & $\begin{array}{l}-0^{\prime} 237 \\
\left(0^{\prime} 364\right)\end{array}$ & $\begin{array}{l}0^{\prime} 049 \\
\left(0^{\prime} 314\right)\end{array}$ & $\begin{array}{l}0^{\prime} 566 \\
\left(0^{\prime} 449\right)\end{array}$ & $\begin{array}{l}-0^{\prime} 013 \\
\left(0^{\prime} 124\right)\end{array}$ & $\begin{array}{l}0^{\prime} 418 \\
\left(1^{\prime} 023\right)\end{array}$ & $\begin{array}{l}1^{\prime} 072 \\
\left(0^{\prime} 907\right)\end{array}$ & $\begin{array}{l}-0^{\prime} 859 \\
\left(0^{\prime} 993\right)\end{array}$ & $\begin{array}{l}0^{\prime} 838^{*} \\
\left(0^{\prime} 432\right)\end{array}$ & 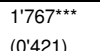 & $\begin{array}{l}1 ' 157 \\
\left(0^{\prime} 891\right)\end{array}$ & $\begin{array}{l}0^{\prime} 365 \\
\left(0^{\prime} 870\right)\end{array}$ & $\begin{array}{l}0^{\prime} 012 \\
\left(0^{\prime} 093\right)\end{array}$ \\
\hline & Medium-edu & $0^{\prime} 8671^{* \star}$ & $0^{\prime} 684^{* * *}$ & 0 '272 & $0^{\prime} 361^{* * *}$ & $-0^{\prime} 098$ & $\begin{array}{l}0 \\
0\end{array}$ & $0^{\prime} 214^{* * *}$ & $0^{\prime} 337^{\star \star *}$ & $0^{\prime} 081^{* *}$ & 0 '249 & 0 & $\begin{array}{l}0^{\prime} 196 \\
\end{array}$ & $\begin{array}{l}-0^{\prime} 069^{*} \\
\end{array}$ & $-2^{\prime} 676^{* *+x}$ & $\begin{array}{l}-0^{\prime} 033 \\
\end{array}$ & $\begin{array}{l}-0^{\prime} 055 \\
\end{array}$ & 0 & $\begin{array}{l}0 \\
0\end{array}$ & $-0^{\prime} 299$ & $1^{\prime} 977^{* \star *}$ & $0,073^{* \star}$ \\
\hline & & (0'3932) & (0'215) & $\left(0^{\prime} 240\right)$ & $\left(0^{\prime} 121\right)$ & (0'097) & $\left(0^{\prime} 137\right)$ & $\left(0^{\prime} 061\right)$ & $\left(0^{\prime} 064\right)$ & $\left(0^{\prime} 035\right)$ & $\left(0^{\prime} 119\right)$ & (0'095) & $\left(0^{\prime} 141\right)$ & $\left(0^{\prime} 038\right)$ & $\left(0^{\prime} 324\right)$ & $\left(0^{\prime} 282\right)$ & $\left(0^{\prime} 333\right)$ & $\left(0^{\prime} 138\right)$ & $\left(0^{\prime} 133\right)$ & (0'274) & $\left(0^{\prime} 281\right)$ & $\left(0^{\prime} 031\right)$ \\
\hline & Low-edu & $17640^{\star \star * *}$ & $0^{\prime} 090$ & $1^{\prime 3} 39^{* * * *}$ & $0^{\prime} 310^{* * * *}$ & $0^{\prime} 032$ & $0^{\prime} 061$ & $-0^{\prime} 024$ & $-0^{\prime} 097^{* * *}$ & $-0^{\prime} 037^{*}$ & $0^{\prime} 011$ & $-0^{\prime} 064$ & $-0^{\prime} 082$ & $-0^{\prime} 035^{*}$ & $-1^{1} 961^{* * *+}$ & $0^{\prime} 362^{* *}$ & $-0^{\prime} 433^{* *+}$ & $0^{\prime} 406^{* * *}$ & $0^{\prime} 196^{* * *}$ & $0^{\prime} 149$ & $0^{\prime} 954^{4+* x}$ & $0^{\prime} 123^{* * *}$ \\
\hline & & $\left(0^{\prime} 2077\right)$ & $\left(0^{\prime} 118\right)$ & $\left(0^{\prime} 123\right)$ & $\left(0^{\prime} 062\right)$ & $\left(0^{\prime} 052\right)$ & $\left(0^{\prime} 070\right)$ & $\left(0^{\prime} 032\right)$ & $\left(0^{\prime} 033\right)$ & $\left(0^{\prime} 019\right)$ & $\left(0^{\prime} 060\right)$ & $\left(0^{\prime} 051\right)$ & $\left(0^{\prime} 081\right)$ & $\left(0^{\prime} 020\right)$ & $\left(0^{\prime} 171\right)$ & $\left(0^{\prime} 146\right)$ & $\left(0^{\prime} 162\right)$ & $\left(0^{\prime} 073\right)$ & $\left(0^{\prime} 069\right)$ & $\left(0^{\prime} 147\right)$ & $\left(0^{\prime} 149\right)$ & $\left(0^{\prime} 018\right)$ \\
\hline \multirow[t]{6}{*}{ Immigrant work } & High-edu & & -1621 & 0,359 & 0'809 & $-1^{\prime} 933^{*}$ & $-3^{\prime} 663^{\star \star \star}$ & $1^{\prime} 337^{* *}$ & $-0^{0} 243$ & $-0^{\prime} 161$ & $-2^{\prime} 520^{* *}$ & $-0^{\prime} 367$ & $1^{\prime} 856$ & & $-2^{2} 835$ & -1561 & $0^{\prime} 237$ & & $1^{\prime} 499$ & $-0^{\prime} 259$ & $1 ' 41$ & $1^{1} 156^{* * *+}$ \\
\hline & & & & $\left(2^{\prime} 45\right.$ & & $\left(10^{0} 3\right.$ & $(135$ & $\left(0^{\prime} 65\right.$ & $\left(0^{\prime} 645\right)$ & $\left(0^{\prime} 352\right)$ & $\left(1^{\prime} 19\right.$ & $\left(1^{1} 05\right.$ & $(144$ & & $(3 \cdot 4 \mathrm{C})(x)$ & $\left(2^{\prime} 9\right.$ & $\left(3^{\prime 2} 2\right.$ & & 7) & (2'879) & (2'787) & 19) \\
\hline & Medium-edu & $-0 ' 5532$ & $3^{\prime} 748^{* * *}$ & $-2^{2} 084^{* *}$ & $-0^{\prime} 108$ & $-1782^{* * *}$ & $-1799^{* * *}$ & $-0^{\prime} 491^{* *}$ & $0^{\prime} 047$ & $0^{\prime} 043$ & $-0^{0} 465$ & $0^{\prime} 048$ & $-0^{\prime} 157$ & $-0^{\prime} 554^{* x+x}$ & $1^{\prime} 949^{*}$ & $0^{\prime} 882$ & $-3^{3} 978^{* * * x}$ & $-1^{1} 420^{* x+x}$ & $0^{\prime} 911^{*}$ & $1^{1} 879^{*}$ & $1^{\prime 3} 390$ & $-0^{\prime} 167$ \\
\hline & & $\begin{array}{l}(14213) \\
\end{array}$ & (0'832) & (0'827) & (0'439) & $\left(0^{\prime} 355\right)$ & $\left(0^{\prime} 486\right)$ & $\left(0^{\prime} 226\right)$ & $\left(0^{\prime} 230\right)$ & (0'121) & $\left(0^{\prime} 413\right)$ & $\left(0^{\prime} 355\right)$ & $\left(0^{\prime} 501\right)$ & $\left(0^{0} 138\right)$ & (1'172) & $\left(1^{\prime} 000\right)$ & (1'156) & $\left(0^{\prime} 500\right)$ & (0'479) & (0'986) & $\left(0^{\prime} 966\right)$ & (0'110) \\
\hline & Low-edu & $-1 ' 5562$ & $1^{\prime \prime} 881$ & $0^{\prime} 816$ & $-3^{\prime} 676^{* * *}$ & $-1^{\prime} 032^{\star \star}$ & $-1^{\prime} 339^{* *}$ & $-0^{\prime 2} 273$ & $1^{\prime} 310^{* * * t}$ & $-0^{\prime} 513^{* * *}$ & $0^{\prime} 873$ & $0^{\prime} 606$ & $-0^{\prime} 227$ & $0^{\prime} 068$ & $-0^{\prime} 601$ & $-3^{\prime} 699^{* \star \star}$ & $7^{\prime} 139^{*+*}$ & & $2^{2} 213^{* * * *}$ & 1'972 & $-2^{2} 345^{*}$ & $0^{\prime} 438^{* * * *}$ \\
\hline & & & & $\left(1^{\prime} 091\right)$ & $\left(0^{\prime} 667\right)$ & $\left(0^{\prime} 493\right)$ & $\left(0^{\prime} 680\right)$ & (0'294) & & & $\left(0^{\prime} 539\right)$ & & $\left(0^{\prime} 67\right.$ & & & $\left(1^{\prime} 42\right.$ & $\left(1^{\prime} 438\right)$ & $\left(0^{\prime} 66\right.$ & $\left(0^{\prime} 6 \varepsilon\right.$ & (1'312) & (1'364) & \\
\hline \multirow[t]{2}{*}{ Capital } & w1kap & $-0^{\prime} 0057^{* *}$ & $-0^{\prime} 004^{* * * *}$ & $0.009^{* * *+}$ & - & - & $\begin{array}{l}-0^{\prime} 001 \\
\end{array}$ & $-0^{\prime} 001^{* *}$ & $-0^{\prime} 001^{* *}$ & $-0^{\prime} 001^{* * *+}$ & $\begin{array}{l}-0^{\prime} 000 \\
\end{array}$ & $-0^{\prime} 002^{* * *}$ & $-0^{\prime} 03^{*+* t}$ & $-0^{\prime} 001^{* * * *}$ & $0^{\prime} 0114^{* * *}$ & $-0^{\prime} 007^{* * *}$ & $0^{\prime} 002$ & $-0^{\prime} 004^{* * *+}$ & $-0^{\prime} 004^{* * * *}$ & $0^{\prime} 009^{* * * *}$ & $0^{\prime} 015^{* * *}$ & $-0^{\prime} 001^{\prime * * *+}$ \\
\hline & & & & & & & & $\left(0^{\prime} 0000\right)$ & $\left(0^{\prime} 000\right)$ & $\left(0^{\prime} 000\right)$ & & & & & & $\left(0^{\prime} 002\right)$ & $\left(0^{\prime} 002\right)$ & $\left(0^{\prime} 001\right)$ & $\left(0^{\prime} 001\right)$ & $\left(0^{\prime} 002\right)$ & $\left(0^{\prime} 002\right)$ & $\left(0^{\prime} 0000\right)$ \\
\hline \multirow[t]{2}{*}{ Land } & w1land & $0^{\prime} 0806^{* *}$ & $-0^{\prime} 052^{\star \star}$ & $-0^{\prime} 079^{+* x+}$ & $-0^{\prime} 073^{*+* *}$ & $0^{\prime} 015$ & $0^{\prime} 015$ & $-0^{\prime} 021^{* * * *}$ & $0^{\prime} 011^{*}$ & $-0^{\prime} 012^{* * x}$ & $-0^{\prime} 078^{t * x}$ & $-0^{\prime} 019^{* *}$ & $-0^{\prime} 027^{* *}$ & $-0^{\prime} 002$ & $0^{\prime} 113^{* * *}$ & - $0^{\prime} 003$ & $0^{\prime} 043$ & $-0^{\prime} 009$ & $0^{\prime} 047^{* * *+}$ & $0^{\prime} 024$ & $0^{\prime} 048^{*}$ & - \\
\hline & & $\left(0^{\prime} 0341\right)$ & $\left(0^{\prime} 022\right)$ & $\left(0^{\prime} 020\right)$ & $\begin{array}{l}\left(0^{\prime} 010\right) \\
\text { (1) }\end{array}$ & $\left(0^{\prime} 009\right)$ & $\left(0^{\prime} 012\right)$ & (0'005) & $\left(0^{\prime} 005\right)$ & $\left(0^{\prime} 003\right)$ & $\begin{array}{l}\left(0^{\prime} 010\right) \\
\text { (a) }\end{array}$ & $\left(0^{\prime} 008\right)$ & $\left(0^{\circ} 012\right)$ & $\left(0^{\prime} 003\right)$ & $\left(0^{\prime} 0281\right)$ & $\left(0^{\prime} 023\right)$ & $\left(0^{\prime} 026\right)$ & $\left(0^{\prime} 012\right)$ & (0'012) & $\left(0^{\prime} 024\right)$ & $\left(0^{\prime} 026\right)$ & $\left(0^{\prime} 003\right)$ \\
\hline Akaike IC. & & $-8,09$ & $-9,36$ & $-9,36$ & $-10,60$ & $-10,67$ & $-10,02$ & $-11,75$ & $-11,62$ & $-12,87$ & $-10,65$ & $-10,74$ & $-10,21$ & $-12,64$ & $-8,48$ & $-8,77$ & $-8,64$ & $-10,24$ & $-10,29$ & $-8,88$ & $-8,84$ & $-13,24$ \\
\hline
\end{tabular}

***, $* *$,* significant at $1 \%, 5 \%$ and $10 \%$ respectively Standard errors are in parentheses 
Table A-3 [continues]. Coefficient Estimates. GLS and SUR estimates. (1996-2005)

\begin{tabular}{|c|c|c|c|c|c|c|c|c|c|c|c|c|c|c|c|c|c|c|c|c|c|c|}
\hline \multirow[t]{5}{*}{$\begin{array}{l}\text { Time-varying Reg. dum. } \\
\text { Native work }\end{array}$} & High-edu & $\begin{array}{l}1 \\
-0^{\prime} 1699\end{array}$ & $\begin{array}{l}2 \\
0^{\prime} 623^{* *+*}\end{array}$ & $\begin{array}{l}3 \\
1 ' 199^{* * *}\end{array}$ & $\begin{array}{l}4 \\
0,116\end{array}$ & $\begin{array}{l}5 \\
-0^{\prime} 027\end{array}$ & $\begin{array}{l}6 \\
-0,311\end{array}$ & $\begin{array}{l}7 \\
0^{\prime} 210^{* *}\end{array}$ & $\begin{array}{l}8 \\
-0^{\prime} 064\end{array}$ & $\begin{array}{l}9 \\
-0^{\prime} 029\end{array}$ & $\begin{array}{l}10 \\
-0^{\prime 2} 219\end{array}$ & $\begin{array}{l}11 \\
-0^{\prime} 112\end{array}$ & $\begin{array}{l}12 \\
0^{\prime} 285^{*}\end{array}$ & $\begin{array}{l}13 \\
0^{\prime} 124^{*}\end{array}$ & $\begin{array}{l}14 \\
-1 ' 194\end{array}$ & $\begin{array}{l}15 \\
0^{\prime} 401\end{array}$ & $\begin{array}{l}16 \\
-1^{\prime} 243^{*}\end{array}$ & $\begin{array}{l}17 \\
0^{\prime} 892^{* * *}\end{array}$ & $\begin{array}{l}18 \\
1^{\prime} 826^{* * *}\end{array}$ & $\begin{array}{l}19 \\
1^{\prime} 905^{* * *}\end{array}$ & $\begin{array}{l}20 \\
0^{\prime} 255\end{array}$ & $\begin{array}{l}21 \\
0^{\prime} 115\end{array}$ \\
\hline & & (0'7565) & $\left(0^{\prime} 194\right)$ & $\left(0^{\prime 2} 277\right)$ & $\left(0^{\prime} 130\right)$ & $\left(0^{\prime} 100\right)$ & (0'262) & $\left(0^{\prime} 100\right)$ & $\left(0^{\prime} 098\right)$ & $\left(0^{\prime} 073\right)$ & $\left(0^{\prime} 154\right)$ & $\left(0^{\prime} 128\right)$ & $\left(0^{\prime} 168\right)$ & $\left(0^{\prime} 073\right)$ & $\left(0^{\prime} 779\right)$ & $\left(0^{\prime} 558\right)$ & $\left(0^{\prime} 664\right)$ & (0'345) & $\left(0^{\prime} 347\right)$ & (0'699) & $\left(0^{\prime} 575\right)$ & $\left(0^{\prime} 071\right)$ \\
\hline & Medium-edu & $\begin{array}{l}1^{\prime} 0502^{* t+} \\
\left(0^{\prime 2} 2949\right)\end{array}$ & $\begin{array}{l}0^{\prime} 306^{* *+} \\
\left(0^{\prime} 078\right)\end{array}$ & $\begin{array}{l}0^{\prime} 954^{+* x+} \\
\left(0^{\prime} 120\right)\end{array}$ & $\begin{array}{l}0^{\prime} 148^{* * *} \\
\left(0^{\prime} 047\right)\end{array}$ & $\begin{array}{l}0^{\prime} 145^{* * *} \\
\left(0^{\prime} 040\right)\end{array}$ & $\begin{array}{l}0^{\prime} 331^{* * *} \\
\left(0^{\prime} 102\right)\end{array}$ & $\begin{array}{l}0^{\prime} 137^{* * *+} \\
\left(0^{\prime} 037\right)\end{array}$ & $\begin{array}{l}0^{\prime} 164^{* * *} \\
\left(0^{\prime} 040\right)\end{array}$ & $\begin{array}{l}0^{\prime} 016 \\
\left(0^{\prime} 027\right)\end{array}$ & $\begin{array}{l}0^{\prime} 132^{+*} \\
\left(0^{\prime} 062\right)\end{array}$ & $\begin{array}{l}0^{\prime} 138^{t * *} \\
\left(0^{\prime} 047\right)\end{array}$ & $\begin{array}{l}0^{\prime} 1136^{* *} \\
\left(0^{\prime} 063\right)\end{array}$ & $\begin{array}{l}-0^{\prime} 069^{* *} \\
\left(0^{\prime} 027\right)\end{array}$ & $\begin{array}{l}-3^{\prime} 133^{+*+*} \\
\left(0^{\prime} 304\right)\end{array}$ & $\begin{array}{l}0^{\prime} 440^{* *} \\
\left(0^{\prime} 211\right)\end{array}$ & $\begin{array}{l}-0^{\prime} 576^{* *} \\
\left(0^{\prime} 263\right)^{2}\end{array}$ & $\begin{array}{l}0^{\prime} 368^{* *+} \\
\left(0^{\prime} 137\right)\end{array}$ & $\begin{array}{l}0^{\prime} 134 \\
\left(0^{\prime} 135\right)\end{array}$ & $\begin{array}{l}-0^{\prime} 366 \\
\left(0^{\prime} 265\right)\end{array}$ & $\begin{array}{l}0^{\prime} 940^{+* *+*} \\
\left(0^{\prime} 240\right)\end{array}$ & $\begin{array}{l}-0^{\prime} 000 \\
\left(0^{\prime} 029\right)\end{array}$ \\
\hline & Low-edu & $1^{\prime 3} 3711^{n+x+2}$ & $\begin{array}{l}0 \\
0\end{array}$ & $1^{\prime 3} 387^{* * * x}$ & $0^{\prime} 338^{t+x}$ & $0^{\prime} 016$ & $0^{\prime} 008$ & $0^{\prime} 028$ & $-0^{\prime} 010$ & $-0^{\prime} 041^{* *}$ & $-0^{\prime} 136^{*+* x}$ & $0^{\prime} 015$ & $\begin{array}{l}-0^{\prime} 004 \\
\end{array}$ & $-0^{0} 037^{* *}$ & $-2237^{* * * x}$ & $0,539^{* t * x}$ & $\begin{array}{l}-0^{\prime} 143 \\
\end{array}$ & $0^{\prime} 211^{* * * *}$ & $\begin{array}{l}0^{\prime} 099 \\
\end{array}$ & $\begin{array}{l}0^{\prime} 086 \\
\end{array}$ & $1 ' 227^{* * *}$ & $0.087^{* * *}$ \\
\hline & & $\left(0^{\prime 1} 1717\right)$ & $\left(0^{\prime} 049\right)$ & $\left(0^{\prime} 077\right)$ & $\left(0^{\prime}, 027\right)$ & $\left(0^{\prime} 024\right)$ & $\left(0^{\prime} 060\right)$ & $\left(0^{\prime} 021\right)$ & $\left(0^{\prime} 022\right)$ & $\left(0^{\prime} 016\right)$ & $\left(0^{\circ} 037\right)$ & $\left(0^{\prime} 027\right)$ & $\left(0^{\prime} 039\right)$ & $\left(0^{\prime} 016\right)$ & $\left(0^{\prime} 177\right)$ & $\left(0^{\prime} 124\right)$ & $\left(0^{\prime} 139\right)$ & $\left(0^{\prime} 077\right)$ & $\left(0^{\prime} 079\right)$ & $\left(0^{\prime} 152\right)$ & $\left(0^{\prime} 143\right)$ & $\left(0^{\prime} 018\right)$ \\
\hline \multirow[t]{5}{*}{ Immigrant work } & High-edu & $-1 ' 8056$ & $-0^{\prime} 136$ & $-0^{\prime} 061$ & $-0^{\prime} 057$ & $0^{\prime} 310$ & $-1^{1} 487^{*}$ & $0^{\prime} 935^{* * *}$ & $-0^{\prime} 248$ & - $0^{\prime} 269$ & $-0^{\prime} 434$ & -0722 & $0^{\prime} 602$ & $0^{\prime} 858^{* * * *}$ & $-5^{\prime} 947^{* *}$ & -1030 & -1751 & $2^{\prime} 840^{* *}$ & $-0^{\prime} 435$ & $0^{\prime} 806$ & $3^{\prime} 514^{*}$ & $0^{\prime} 566^{* *}$ \\
\hline & & (2'6278) & $\left(0^{\prime} 677\right)$ & $\left(0^{\prime} 971\right)$ & $\left(0^{\prime} 417\right)$ & $\left(0^{\prime} 370\right)$ & $\left(0^{\prime} 866\right)$ & $(0 ; 327)$ & $\left(0^{\prime} 340\right)$ & $\left(0^{\prime} 242\right)$ & $(0,522)$ & $\left(0^{\prime \prime} 450\right)$ & $\left(0^{\prime} 578\right)$ & (0'258) & (2'707) & (1'829) & $\left(2^{\prime} 124\right)$ & (1'211) & $\left(1^{1} 172\right)$ & ('292) & (1'892) & $\left(0^{\prime} 253\right)$ \\
\hline & Medium-edu & $3^{\prime} 2888^{* * *}$ & $1^{1} 051^{* * * *}$ & $1269^{* * x}$ & $-0^{-1730 * *+*}$ & $-1^{1} 108^{t+x+}$ & $\begin{array}{l}-0^{\prime} 876^{* *} \\
\left(0^{*} 370\right)\end{array}$ & $-0^{\prime} 321^{* *}$ & $-0^{\prime} 101$ & $\begin{array}{l}-0^{\prime 2} 237^{* *} \\
\left(0^{\prime} 0999\right.\end{array}$ & $-11^{1} 182^{* * * *}$ & $\begin{array}{l}-0^{\prime} 200 \\
0^{\prime} 777\end{array}$ & $-0^{\prime} 147$ & $-0^{\prime} 358^{* * *+}$ & $0^{\prime} 549$ & $-1^{\prime} 364^{*}$ & $-2^{2} 298^{* *}$ & $-2081^{* * *+}$ & $\begin{array}{l}-0^{\prime} 035 \\
-0358\end{array}$ & $2^{2} 541^{\star *}$ & $1^{\prime} 347^{\star}$ & $-0^{\prime} 271^{* * * *}$ \\
\hline & Low-edu & 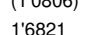 & $1^{\prime} 454^{* * *}$ & $\begin{array}{l}-0^{\prime} 220 \\
-\end{array}$ & - & 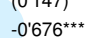 & -1'435 & 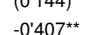 & $\begin{array}{l}-0^{\prime} 364 \\
-(1 / 7)\end{array}$ & 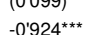 & 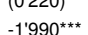 & $-0^{\prime 2} 288$ & $\begin{array}{l}0.028 \\
0.028\end{array}$ & $\begin{array}{l}-0^{\prime} 051 \\
-\end{array}$ & 1243 & $1^{1} / 500$ & (1'125) & 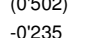 & $\begin{array}{l}1080) \\
2083^{* * *}\end{array}$ & $2676^{*}$ & 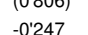 & $\left.0^{\prime} 230\right)$ \\
\hline & & (1'5596) & $\left(0^{\prime} 460\right)$ & $\left(0^{\prime} 561\right)$ & $\left(0^{\prime} 301\right)$ & (0'222) & $\left(0^{\prime} 560\right)$ & $\left(0^{\prime} 194\right)$ & 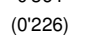 & $\left(0^{\prime} 147\right)$ & (0'349) & $\begin{array}{l}\left(0^{\prime 2} 246\right) \\
\text { (1) }\end{array}$ & (0'319) & $\left(0^{\prime} 150\right)$ & $(1 ' 607)$ & $\left(1^{\prime} 136\right)$ & (1'292) & (0732) & $\left(0^{\prime} 707\right)$ & (1'437) & $\left(1^{\prime} 141\right)$ & $\left(0^{\prime} 145\right)$ \\
\hline Capital & w1kap & $-0^{\prime} 0067^{* * *}$ & $\begin{array}{l}-0^{\prime} 000 \\
0\end{array}$ & $0^{\prime} 007^{* \star * *}$ & $0^{\prime} 002^{* * *}$ & $-0^{\prime} 00^{1+x}$ & $-0^{\prime} 002^{* *}$ & $-0^{\prime} 001^{* * *}$ & $-0^{\prime} 00^{* *}$ & $-0^{\prime} 01^{* * * x}$ & $-0^{\prime} 001^{* *}$ & $-0^{\prime} 02^{* * *}$ & $-0^{\prime} 002^{2+* x}$ & $-0^{\prime} 01^{* * *+}$ & $0^{\prime} 012^{* * *}$ & $-0^{\prime} 004^{* * *+}$ & $\begin{array}{l}-0^{\prime} 001 \\
-001\end{array}$ & $-0^{\prime} 005^{* * *}$ & $-0^{\prime} 003^{t+x}$ & $0^{\prime} 009^{* * *}$ & $\begin{array}{l}0^{\prime} 012^{t+x+x} \\
\left(0^{\prime}+0 ?\right)\end{array}$ & $-0^{\prime} 001^{* * *}$ \\
\hline Land & wiland & $\begin{array}{l}0^{\prime} 07205^{* *} \\
\left(0^{\prime} 0339\right)\end{array}$ & $\begin{array}{l}-0^{\prime} 003 \\
\left(0^{\prime} 010\right)\end{array}$ & $\begin{array}{l}-0^{\prime} 101^{* * * *} \\
\left(0^{\prime} 013\right)\end{array}$ & $\begin{array}{l}-0^{\prime} 046^{* *+*} \\
\left(0^{\prime} 005\right)\end{array}$ & $\begin{array}{l}-0^{\prime} \cdot 008 \\
\left(0^{\prime} 005\right)\end{array}$ & $\begin{array}{l}0^{\prime} 003 \\
\left(0^{\prime} 012\right)\end{array}$ & $\begin{array}{l}-0^{\prime} 023^{+*+*} \\
\left(0^{\prime} 004\right)\end{array}$ & $\begin{array}{l}-0^{\prime} 001 \\
\left(0^{\prime} 005\right)\end{array}$ & $\begin{array}{l}-0^{\prime} 010^{* * * *} \\
\left(0^{\prime} 003\right)\end{array}$ & $\begin{array}{l}-0^{\prime} 077^{* * * *} \\
\left(0^{\prime} 007\right)\end{array}$ & $\begin{array}{l}-0^{\prime} 021^{* * *} \\
\left(0^{\prime} 005\right)\end{array}$ & $\begin{array}{l}-0^{\prime} 017^{* *} \\
\left(0^{\prime} 007\right)\end{array}$ & $\begin{array}{l}-0^{\prime} 002 \\
\left(0^{\prime} 003\right)\end{array}$ & $\begin{array}{l}0^{\prime} 154^{* * *} \\
\left(0^{\prime} \prime 035\right)\end{array}$ & $\begin{array}{l}-0^{\prime} 077^{*+*+1} \\
\left(0^{\prime} 026\right)\end{array}$ & $\begin{array}{l}-0^{\prime} 028 \\
\left(0^{\prime} 027\right)\end{array}$ & $\begin{array}{l}-0^{\prime} 033^{* *} \\
\left(0^{\prime} 015\right)\end{array}$ & $\begin{array}{l}0^{\prime} 043^{* * * *} \\
\left(0^{\prime} 016\right)\end{array}$ & $\begin{array}{l}0^{\prime} 087^{\prime * *} \\
\left(0^{\prime} 030\right)\end{array}$ & $\begin{array}{l}0 \\
0105^{* * *} \\
\left(0^{\prime} 028\right)\end{array}$ & $\begin{array}{l}-0^{\prime} 003 \\
\left(0^{\prime} 003\right)\end{array}$ \\
\hline aike IC. & & -9.12 & -1182 & -1105 & -1283 & -1291 & -1113 & -13.14 & -13.10 & -1366 & -1239 & -1262 & -1213 & -1381 & -906 & -976 & -9.59 & -10.57 & $-10,62$ & -932 & -9.64 & -1372 \\
\hline
\end{tabular}

Note: $* * *, * * *$ significant at $1 \%, 5 \%$ and $10 \%$ respectively. Standard errors are in parentheses. 